\title{
Simulating the Evolution of Fluid Underpressures in the Great Plains, by Incorporation of Tectonic Uplift and Tilting, with a Groundwater Flow Model
}

\author{
Amjad M. J. Umari $\mathbb{D}^{1},{ }^{1}$ Philip H. Nelson, ${ }^{2}$ Chris Fridrich, ${ }^{3}$ and Gary D. LeCain ${ }^{4}$ \\ ${ }^{1}$ Earth Systems Modeling Branch, Integrated Modeling and Prediction Division, Water Mission Area, US Geological Survey (USGS), \\ Denver Federal Center, P.O. Box 25046, MS 406, Lakewood, CO 80225, USA \\ ${ }^{2}$ Central Energy Resources Science Center, US Geological Survey (USGS), Denver Federal Center, P.O. Box 25046, MS 964, \\ Lakewood, CO 80225, USA \\ ${ }^{3}$ Central Energy Resources Science Center, US Geological Survey (USGS), Denver Federal Center, P.O. Box 25046, MS 980, \\ Lakewood, CO 80225, USA \\ ${ }^{4}$ Earth Systems Processes Division, Water Mission Area, US Geological Survey (USGS), Denver Federal Center, P.O. Box 25046, \\ MS 406, Lakewood, CO 80225, USA
}

Correspondence should be addressed to Amjad M. J. Umari; mjumari@usgs.gov

Received 13 May 2017; Revised 18 August 2017; Accepted 1 October 2017; Published 26 February 2018

Academic Editor: John A. Mavrogenes

Copyright (C) 2018 Amjad M. J. Umari et al. This is an open access article distributed under the Creative Commons Attribution License, which permits unrestricted use, distribution, and reproduction in any medium, provided the original work is properly cited.

\begin{abstract}
Underpressures (subhydrostatic heads) in the Paleozoic units underlying the Great Plains of North America are a consequence of Cenozoic uplift of the area. Based on tectonostratigraphic data, we have developed a cumulative uplift history with superimposed periods of deposition and erosion for the Great Plains for the period from $40 \mathrm{Ma}$ to the present. Uplift, deposition, and erosion on an $800 \mathrm{~km}$ geologic cross-section extending from northeast Colorado to eastern Kansas is represented in nine time-stepped geohydrologic models. Sequential solution of the two-dimensional diffusion equation reveals the evolution of hydraulic head and underpressure in a changing structural environment after $40 \mathrm{Ma}$, culminating in an approximate match with the measured presentday values. The modeled and measured hydraulic head values indicate that underpressures increase to the west. The 2 to 0 Ma model indicates that the present-day hydraulic head values of the Paleozoic units have not reached steady state. This result is significant because it indicates that present-day hydraulic heads are not at equilibrium, and underpressures will increase in the future. The pattern uncovered by the series of nine MODFLOW models is of increased underpressures with time. Overall, the models indicate that tectonic uplift explains the development of underpressures in the Great Plains.
\end{abstract}

\section{Introduction}

The existence of underpressures (subhydrostatic hydraulic head values, Appendix A), in the geologic units that underlie the Great Plains $[1,2]$ of North America has been well documented. Appendix A presents the theoretical basis for defining and quantifying underpressure.

These underpressures are subsurface zones where the hydraulic head of confined aquifers is less than the elevation of the water table (Figure 1 and Appendix A). Belitz and Bredehoeft [3] provide a summary of underpressures identified in the Texas Panhandle [4], the San Juan Basin in New Mexico [5], the Denver Basin in Nebraska [6], and numerous other examples. Nelson et al. [7] used water levels measured in wells and oil and gas drillstem tests to quantify the underpressures in the Paleozoic units along a cross-section from eastern Colorado to eastern Kansas (Figure 2). The data and analysis identified large underpressures in the west, equivalent to several hundred meters of water. As noted by Nelson et al. [7] and Belitz and Bredehoeft [3], underpressure values are greatest in the west and are least where the geologic units crop out in the east. 




FIgURE 1: The definition of underpressure. $D$, depth of measuring point; WT, elevation of water table; GL, elevation of ground level; Up_real, actual underpressure as head drop; Up_approx, head drop from land surface; $p$, pressure; $\gamma$, unit weight of water; $Z$, elevation of formation.

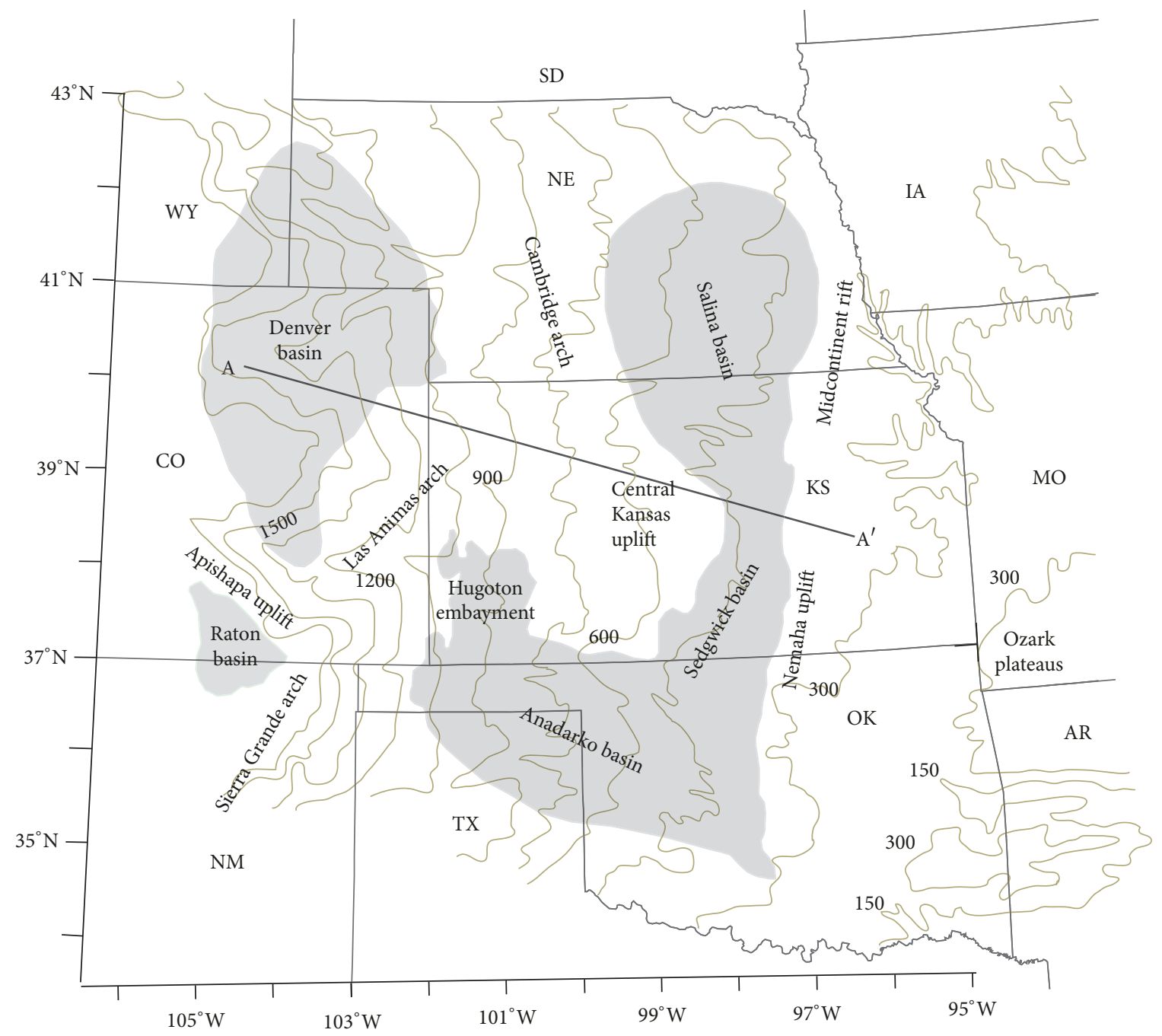

FIgure 2: Physiographic map of study area, in the Great Plains, from Nelson et al. ([7], Figure 1). The figure shows land surface elevation contours (m), state lines, location of structural features, sedimentary basins (shaded), and the $800 \mathrm{~km}$ cross-section line A- $\mathrm{A}^{\prime}$. 
A hydrodynamic model is deemed appropriate for the confined aquifers of the Great Plains. For example, Belitz and Bredehoeft [3], p. 1356, postulate that

Generally, subnormal fluid pressures might be found in any subaerial, topographically tilted, structural basin capped by a thick sequence of low-permeability rocks (i.e., shale or evaporites). The tilt can provide the topographic driving force for the fluid flow. The low-permeability cap can provide insulation from the elevation head of the water table, and the structure can provide the mechanism for reducing permeability in the basin deep that allows for better hydrologic connection to low-elevation outcrops than to high-elevation outcrops.

They present a hydrodynamic model of the Denver Basin and conclude that the underpressures are due to groundwater flow combined with limited recharge. Sorenson [8] concluded that the underpressures in the Panhandle-Hugoton gas field of Kansas, Oklahoma, and Texas were due to fluid flow and controlled by the reservoir outcrop elevations in eastern Kansas. Analysis of groundwater flow in the Dakota Sandstone aquifer of Kansas and southeastern Colorado concluded that the underpressure values in the Dakota Aquifer were due to groundwater discharge at the unit outcrop in eastern Kansas [9]. Nelson et al. [7] also concluded that the control of the hydraulic head values in Paleozoic strata in Colorado and Kansas was also exerted by the outcrops in eastern Kansas and Oklahoma.

A review of the literature finds that the work to date has provided some insight on our conceptual and numerical understanding of the existence and development of underpressure in the Great Plains. However, no one has attempted to incorporate the structural changes that may have provided the driving force. The key to a numerical groundwater flow model that would be able to represent the development of underpressure over geologic time in the Great Plains is, in our view, the inclusion of the following: (1) the history of uplift and tilting, which is recorded in the tectonostratigraphy of the Great Plains, and (2) the hydrologic framework of the Great Plains. Over the last 70 million years, the area that is now the Great Plains has undergone the natural geologic processes of uplift, tilting, subsidence, erosion, and deposition. Major structural changes include the Laramide orogeny and formation of the Rocky Mountains, subsidence of the Denver Basin, uplift of the Colorado Rockies, and erosion and exposure of the Paleozoic units in eastern Kansas. The area of the Great Plains has transitioned from the bottom of a large Cretaceous inland sea, the Cretaceous Western Interior Seaway, to a sea of grass elevated to over a mile above sea level at the base of the Rocky Mountains.

We hypothesize that underpressure is a condition driven by structural changes (primarily differential uplift) that occurred during the Cenozoic Era, resulting in exposure of outcrops in the eastern Great Plains and tilt of the land surface. To investigate this hypothesis and incorporate the structural changes in the Great Plains over the last 40 million years, we use a numerical groundwater flow model called
MODFLOW [10], to solve the two-dimensional diffusion equation (the "groundwater flow equation" of hydrologists), and find the variation of hydraulic head $h$ with distance $x$, elevation $y$, and time $t$ :

$$
\frac{\partial^{2} h}{\partial x^{2}}+\frac{\partial^{2} h}{\partial y^{2}}=\left[\frac{S_{s}}{K} \frac{\partial h}{\partial t}\right]
$$

where $K$ is hydraulic conductivity in $\mathrm{m} \mathrm{s}^{-1}$ and $S_{s}$ is specific storage, with dimensions of $\mathrm{m}^{-1}$. These terms and others used in this paper are presented under the Definitions of Terms.

Because MODFLOW utilizes a fixed geometry and does not incorporate time-varying structural changes, we elected to run a sequence of nine numerical models $(n=1, \ldots, 9)$, each representing a limited time interval, such as 27 to $18 \mathrm{Ma}$, with the geometry appropriate for that time interval. The structural changes required to transition from model $n$ to model $n+1$, mainly elevation and tilt as calculated in a spreadsheet, are summed with the head values $h$ computed for model $n$. These augmented values of $h$ then serve as starting values for model $n+1$. This procedure is repeated until $n=9$ and a solution for $h$ is obtained at $0 \mathrm{Ma}$. Equation (1) is solved with uniform time steps of one year to ensure proper numerical solution of the transient groundwater flow, diffusion equation (see (1)), whereas the structural changes incorporated in the nine models are implemented over durations ranging from 1 to 9 million years depending on whether the uplift as a function of time was steep or shallow, to keep the total uplifts within all time intervals comparable.

\section{The Geologic Setting}

The sequence of nine structural models rests upon the history of uplift of the Great Plains, which is recorded in its tectonostratigraphy. Appendix B gives further details.

Eaton $[11,12]$ interpreted the Great Plains as the eastern flank of a huge antiformal uplift that is centered on the Rio Grande rift and includes the Colorado Plateau as its western flank (Figures 3, 4, and 5). The Rio Grande rift, in turn, is partly coincident with the southern Rocky Mountains, and the current high elevation of the Rocky Mountains dates only to uplift of this antiformal bulge, which entirely postdates the original formation of these mountains in the Laramide ( $\sim 70$ to $\sim 40 \mathrm{Ma}$ ) orogeny. Eaton [11] called this giant domal uplift the Alvarado ridge. From shortly after the end of the Laramide orogeny (at $\sim 40 \mathrm{Ma}$ ) to just before the beginning of formation of the Rio Grande rift (at $\sim 27 \mathrm{Ma}$ ), subduction continued along the west coast of North America; however, contractional uplift of the southern Rocky Mountains had ceased. The onset of Rio Grande rifting to the southwest of the study area (near the central Colorado/New Mexico border), at $\sim 27 \mathrm{Ma}$, was accompanied by an early stage of uplift [13].

The interval from $\sim 18$ to $\sim 4.5 \mathrm{Ma}$ on the Great Plains was characterized by the deposition of the Ogallala Formation, which is a vast apron of debris shed from the crest of the Alvarado ridge onto the Great Plains, and which is an important water-table aquifer in a major part of the Great Plains (Figure 5). Deposition of the Ogallala therefore reflects the uplift of the Alvarado ridge [14]. The Ogallala contains 


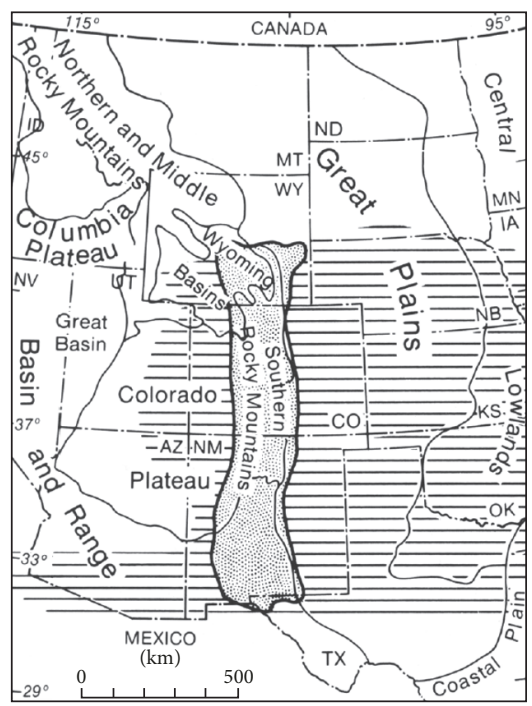

FIgURE 3: Index map showing key elements of the Eaton Alvarado ridge in relation to political boundaries (dash-dot lines) and physiographic province boundaries (thin solid lines); some of the latter provinces are grouped together and labelled. The region around the crest of the Alvarado ridge is outlined by a heavy solid line (Figure 2 of [11]).

cobbles derived from the Rocky Mountains as far east as the Colorado-Kansas border, an indicator of its deposition on an already tilted and partially uplifted surface. Presumably, continued uplift and tilting during deposition of the Ogallala eventually created grades steep enough to end deposition and initiate erosion. Strong tilting of the Ogallala in the western part of the Great Plains indicates that at least about half of the uplift and tilting of the Great Plains occurred after 4.5 Ma. Current slopes across the Great Plains average $\sim 10^{-3}$. This, combined with the sustained pattern of downcutting throughout the Great Plains since $\sim 4.5 \mathrm{Ma}$, reflects a much stronger pattern of uplift since $\sim 4.5 \mathrm{Ma}$ than in the preceding $\sim 27$ to $\sim 4.5 \mathrm{Ma}$. Whereas it is difficult if not impossible to quantify this, it appears likely that at least about half of the total uplift of the Great Plains occurred in the interval from $\sim 4.5 \mathrm{Ma}$ to the present.

\section{Methodology}

3.1. Understanding the Geology and Quantifying Structural Changes. A geologic map of the study area and a crosssection along line $A-A^{\prime}$ are presented in Figures 6 and 7 , respectively. From the geologic evidence presented in Appendix B, we have estimated an uplift history for the Great Plains for the period of $27 \mathrm{Ma}$ to the present plotted as cumulative uplift with time, along with superimposed periods of deposition and erosion (Figure 8). Uplift during the Laramide orogeny (70-40 Ma) was incorporated as $250 \mathrm{~m}$ of uplift at the Rocky Mountain Front and $50 \mathrm{~m}$ of uplift in the east, relative to the Cretaceous Western Interior Seaway. Uplif $\mathrm{t}$ during the period of 40 to $27 \mathrm{Ma}$ was assumed to be zero (Appendix B).
3.2. Assembling the Present-Day Geofluid Underpressure Data. Nelson et al. [7] present six maps of present-day hydraulic heads in the Paleozoic rocks that underlie the Great Plains. These values are derived from pressures measured in drillstem tests in oil and gas wells, combined with water levels measured in water wells. The maps extend northward from the Anadarko Basin in Oklahoma to southern Nebraska and eastward from eastern Colorado to eastern Kansas and Oklahoma. On all six maps, the potentiometric surfaces approach land elevation in the vicinity of the geologic unit outcrops in the eastern part of the mapped area. However, as land elevation rises to the west (Figure 2), the potentiometric surfaces drop below land surface, and underpressures develop. Figures 9,10 , and 11 present the potentiometric surfaces from three of the maps presented in Nelson et al. [7]. The figures indicate that the hydraulic gradient is smaller in central and eastern Kansas (wide contour spacing) and larger in western Kansas and eastern Colorado (narrow contour spacing). The smaller hydraulic gradient in central and eastern Kansas may be attributed to hydraulic conductivity values greater than those of western Kansas and eastern Colorado.

Figure 12 presents the hydraulic head values along crosssection A-A' (Figure 6) for the six potentiometric surfaces in Nelson et al. [7]. Figure 12 indicates that the hydraulic head data fall into two groups: the Wolfcampian, Virgilian, and Missourian profiles form one group with higher head values and higher gradients, and the Mississippian and CambrianOrdovician-Silurian profiles form a second group with lower head values and lower gradients. The Desmoinesian profile matches the low-head, low-gradient character in the east but displays high head values in the west. Replication of these features is a primary goal of the hydrologic model described in this paper.

\subsection{Creating and Calibrating the Hydrologic Model to Simulate} Structurally Driven Underpressures. The creation and calibration of the hydrologic model is best summarized in a flow chart as shown in Figure 13.

Each flow chart element \# is referred to herein as FE \# and is related to a section of the paper in Table 1.

Part one of the model creation and calibration process includes incorporating tectonic uplift, deposition, and erosion.

The sequence of MODFLOW models created for this work (represented conceptually by FE \# (3) in the flow chart of Figure 13; and listed in Table 3) is based on the geologic cross-section running from northeastern Colorado to eastern Kansas by Nelson et al. [7]. The line of the cross-section is shown in Figures 2 and 6 and the cross-section in Figure 7. The cross-section cuts through, from top to bottom, the Cenozoic strata [Tertiary Laramide Basin Fill], the Mesozoic strata [Cretaceous Pierre and Niobrara Shales and Dakota Sandstone; Jurassic sediments], and the Paleozoic strata [Permian (Upper Permian, Lower Permian: Wolfcampian), Pennsylvanian (Virgilian, Missourian, Desmoinesian, Basal Pennsylvanian), Mississippian, Silurian, Ordovician, and Cambrian formations]. The geologic time line starts $40 \mathrm{Ma}$, the end of the Laramide orogeny and the beginning of a quiescent 


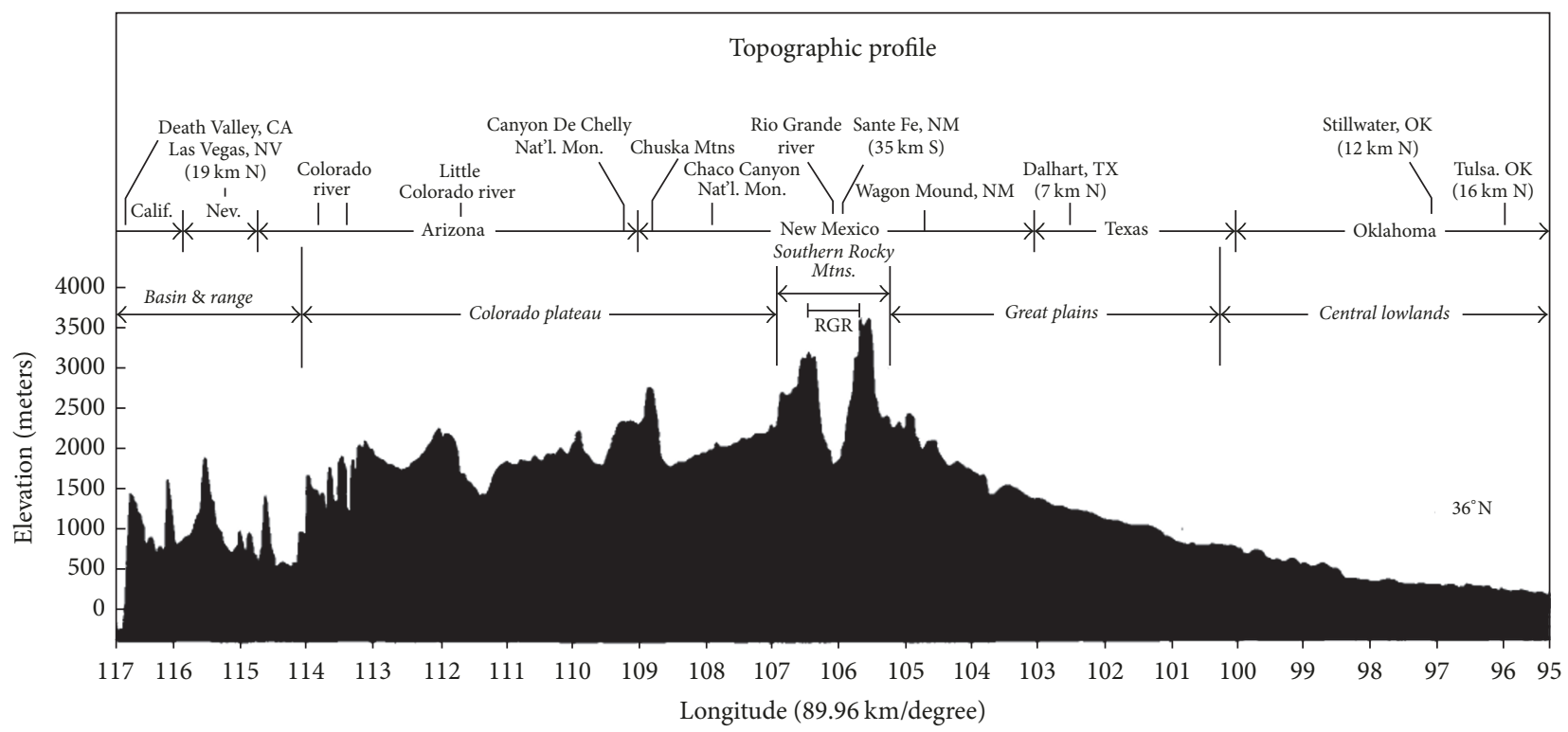

Figure 4: Cross-section of the Eaton Alvarado ridge along the $36^{\circ} \mathrm{N}$ parallel. The cross-section shows the Rio Grande rift incised into the Alvarado ridge (Figure 3 of [11]).

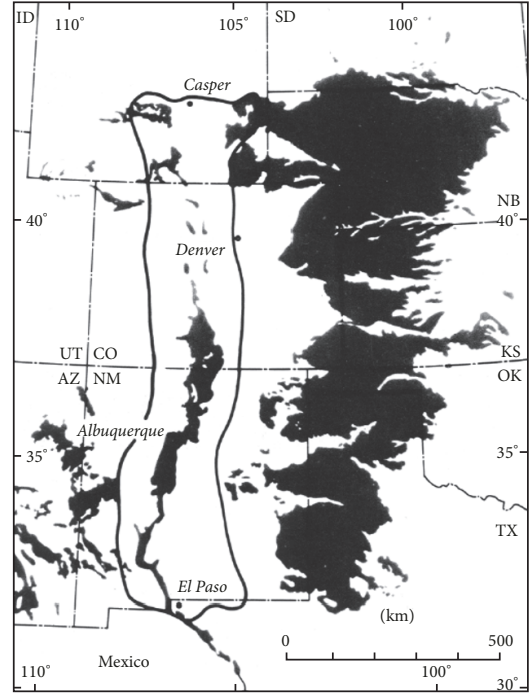

FIGURE 5: Distribution of Miocene and Pliocene sedimentary rocks (shaded) on the Eaton Alvarado ridge. These sediments lie in a chain of deep medial grabens (like in the Rio Grande rift in NM and southern $\mathrm{CO}$ ) and in thin blankets on the flanking rises of the ridge. The region around the crest of the Alvarado ridge is outlined by a heavy solid line. The large continuous shaded area in the east, running from Nebraska down to the Texas Panhandle, is the Ogallala Formation (Figure 4 of [11]).

period lasting until the onset of uplift of the Great Plains at $27 \mathrm{Ma}$. The results from model 1 represent an equilibrium potentiometric regime for the geometry existing at $27 \mathrm{Ma}$. Wellbore information from 27 oil and gas wells (N. J. Gianoutsos, USGS, written commun., 2014), which is background to data published in Nelson et al. [7], was used to define the tops and bottoms of geologic formations (Figure 7). These data were also used to calculate formation thicknesses in each borehole using a Microsoft Excel spreadsheet. The MODFLOW preprocessor program ModelMuse [15] was used to create the model geometry. Figure 14 presents the first in the sequence of 9 cross-sectional models, representing the period from 40 to $27 \mathrm{Ma}$. The MODFLOW model has 10 "layers" spanning the vertical $z$ direction (Table 2), 26 "columns" spanning the horizontal $x$ direction, and 1 "row" perpendicular to the page (because we are representing threedimensional reality by a 2-dimensional section in the plane of a report page). Each layer-column-row element of the model is referred to as a "cell." The thicknesses of the formations in each borehole, as calculated above, define the elevations of the tops and bottoms of these formations/layers in Figure 14. A stratigraphic column (Table 2) presents the ages, lithologies, hydrogeologic unit, and thicknesses of these 10 model layers (see Appendix B for background). Even though the Ogallala, Laramide Basin Fill, and Dakota are shown in Table 2 to be aquifers, they were treated as aquitards, with a $K$ of 1 $\times 10^{-6} \mathrm{~m} / \mathrm{d}$, essentially to remove them from the analysis and emphasize the flow regimes through the deeper units where head data are available. The Ogallala, Laramide Basin Fill, and Dakota are only included for the sake of geologic completeness and for the option to expand the modeling to the upper horizons if desired in the future. The sensitivity analysis Table 7 (to be introduced later under Sensitivity Analysis) shows that if $K$ in the Ogallala, Laramide Basin Fill, and Dakota were to be increased by 2 orders of magnitude, the conceptual model of isolation of the deeper units would be compromised and $h$ in the Wolfcampian would change by -8.95 percent. Figures 14, 15, and 16 present the model grids for the periods ending at 27,18 , and $4.5 \mathrm{Ma}$, respectively.

To investigate the hypothesis that underpressure is a condition driven by structural changes that occurred during the Cenozoic Era, such as exposure of outcrops in the eastern 




FIgURE 6: Geologic map of study area from Nelson et al. ([7], Figure 4) with the $800 \mathrm{~km}$ cross-section A-A'.

Great Plains and tilt of the land surface, the sequence of MODFLOW models was developed (FE \#'s (3a), (3b), .., (3i) of the flow chart in Figure 13; Table 3). This sequence of models represents our hydrologic modeling of the specific geologic events of uplift, deposition, and erosion, shown in Figure 8. The goal of the modeling was that the calculated heads for the ninth and last model of the sequence approximate the actual present-day hydraulic head data values observed in the field.

This model sequence (Table 3 ) consists of 9 multi-millionyear, coarse-grid cross-sectional models with 10 layers that simulate the period of uplift, deposition, and erosion from $27 \mathrm{Ma}$ to the present, represented in Figure 8. The structural deformation ends with a net uplift of $1.6 \mathrm{~km}$ in the west along the Rocky Mountain Front relative to eastern Kansas. Models are named for the end of a time period; so the $27 \mathrm{Ma}$ model simulates the 13-million-year period from 40 to $27 \mathrm{Ma}$. The progression of uplift, deposition, and erosion is portrayed in four cross-sections (Figures 14, 15, 16, and 7), starting with the $27 \mathrm{Ma}$ model and concluding with the $0 \mathrm{Ma}$ model, which also serves as the present-day geologic cross-section (Figure 7). The primary effects through time are (1) the increased tilting of the land surface, (2) the increased tilting of all strata, and
(3) the higher elevation of the entire section. Elevation gain, tilt, and the development of a concave surface with time are also apparent on the stacked land surfaces of the nine models (Figure 17).

3.3.1. Uplift, Deposition, and Erosion. Uplift, deposition, and erosion were incorporated into each of the sequences of MODFLOW models. Table 4 presents the percent of total uplift (PTU) and cumulative percent of total uplift (CpTU) calculated for the 9 model intervals. As shown in Figure 8, post-Laramide uplift occurs from $27 \mathrm{Ma}$ to the present, superimposed first by a period of deposition of the Ogallala, from 18 to $4.5 \mathrm{Ma}$, and then a period of erosion from $4.5 \mathrm{Ma}$ to the present.

Figure 7 represents the present-day surface elevations. Figure 14 represents the land surface elevation at $27 \mathrm{Ma}$. The difference in elevation between these two surfaces represents the total uplift (TU), which varies with distance, $\mathbf{x}$, from the Golden Fault at the Rocky Mountain Front. The $27 \mathrm{Ma}$ land surface is a tilted plane (seen as the straight line top of the twodimensional cross-section of Figure 14), whereas the presentday land surface of Figure 7 is concave upwards. The upward 


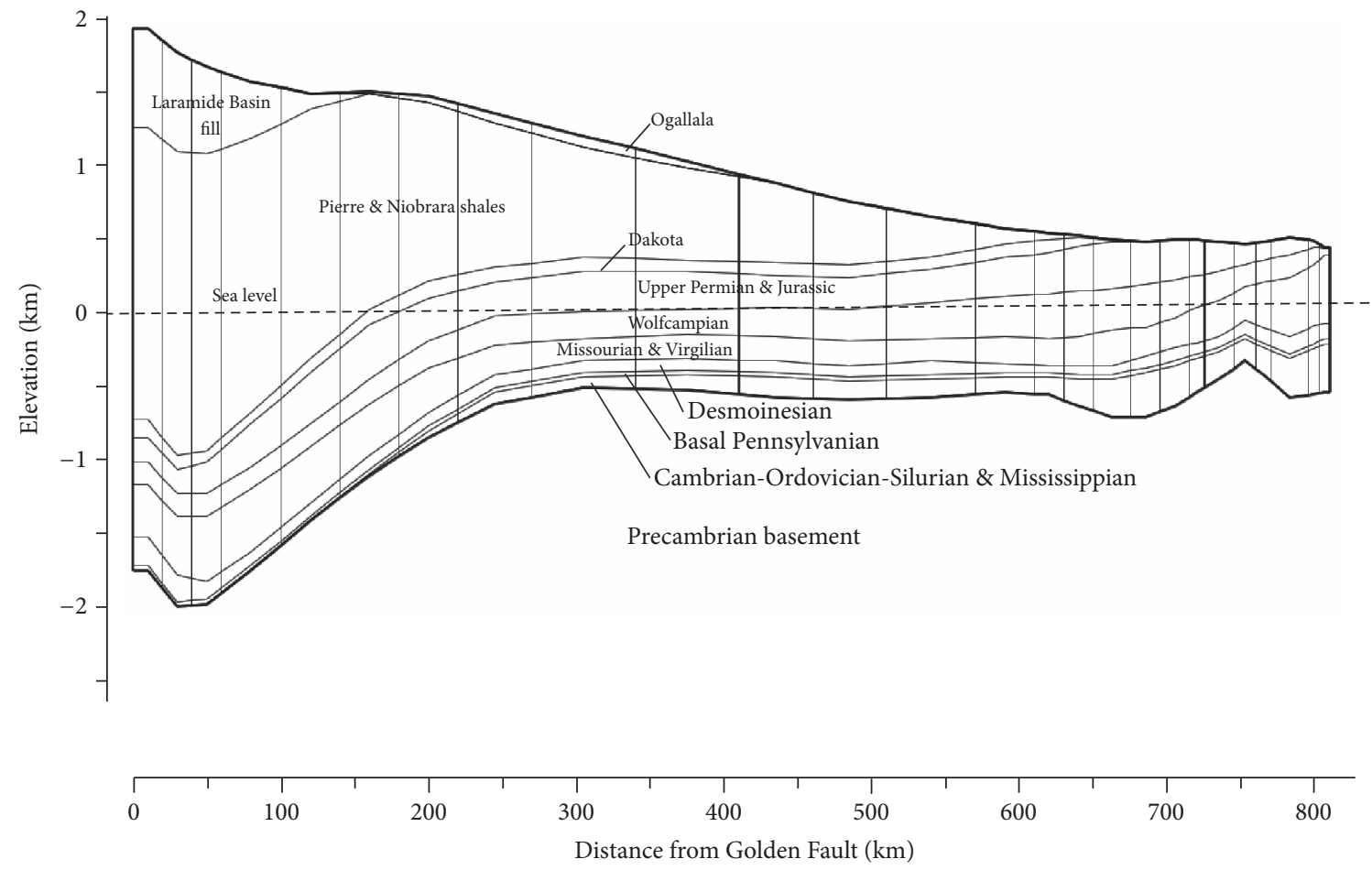

FIgURE 7: Present-day geologic cross-section along line A-A' (Figure 6) with names of geohydrologic units. Modified from Nelson et al. [7]. Vertical lines are both well locations and internal model boundaries.

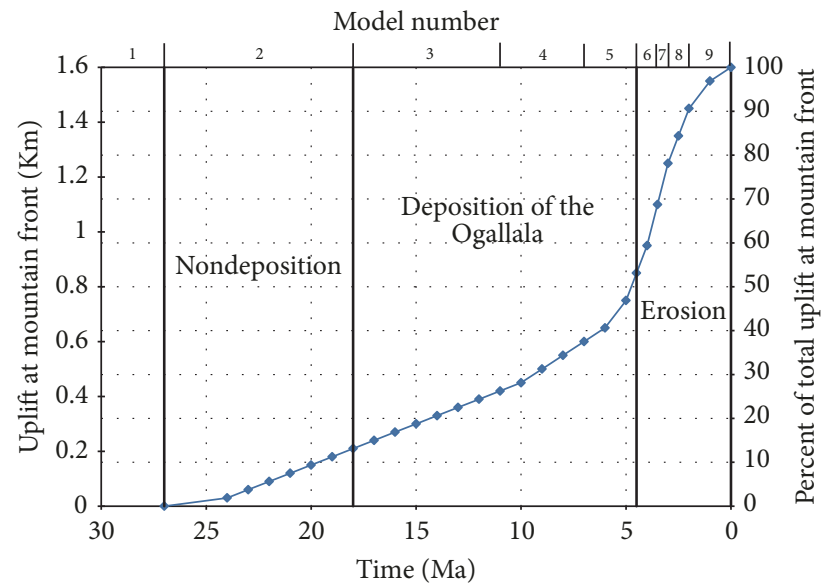

FIGURE 8: Estimated cumulative uplift and percent of total uplift as a function of time since $27 \mathrm{Ma}$, with model numbers and superimposed periods of deposition and erosion.

concavity represents increased uplift as the Rocky Mountains are approached from the east.

The uplift process assumes the land surface at $27 \mathrm{Ma}$, shown in Figure 14, is a plane (straight line in two dimensions) rising from $50 \mathrm{~m}$ ASL in the east to $250 \mathrm{~m}$ ASL in the west. Because the uplift from 27 to $18 \mathrm{Ma}$ is 13.125 percent of total uplift (PTU in Table 4), 13.125 percent of total uplift calculated above is added to the $27 \mathrm{Ma}$ land surface of Figure 14 to obtain the $18 \mathrm{Ma}$ land surface of Figure 15. This process is repeated for 18 to $11 \mathrm{Ma}, 11$ to $7 \mathrm{Ma}, 7$ to $4.5 \mathrm{Ma}$, and so on, to calculate the uplift at each stage of the modeling sequence, ending with the $0 \mathrm{Ma}$ land surface shown in the geologic cross-section of Figure 7.

The model also includes periods of deposition. Deposition of the Ogallala takes place from 18 to $4.5 \mathrm{Ma}$ (Figure 8). It was further assumed that the maximum deposition, at $4.5 \mathrm{Ma}$, was $183 \mathrm{~m}$ at $\mathbf{x}=340 \mathrm{~km}$, near the midpoint and thickest location of the Ogallala Formation at $4.5 \mathrm{Ma}$, shown in Figure 16. We then assumed a linear spatial interpolation of Ogallala thickness from $183 \mathrm{~m}$ at $\mathbf{x}=340 \mathrm{~km}$ to $0 \mathrm{~m}$ at both east $(\mathbf{x}=810 \mathrm{~km})$ and west $(\mathbf{x}=0 \mathrm{~km})$ ends of the model, at $4.5 \mathrm{Ma}$. We then linearly interpolated with time from a thickness of $0 \mathrm{~m}$ at $18 \mathrm{Ma}$ to the Ogallala thickness at $4.5 \mathrm{Ma}$ to obtain the Ogallala deposition thickness at the intermediate times between 18 and $4.5 \mathrm{Ma}$, namely, 11 and $7 \mathrm{Ma}$. The Ogallala deposition was added to the uplifted surfaces of the 11, 7, and 4.5 Ma models to obtain the final surfaces of these models.

Uplift and deposition, as explained above, define the 4.5 Ma land surface shown in Figure 16. The model also includes erosion that occurred from 4.5 Ma to the present. The land surface at $4.5 \mathrm{Ma}$ was eroded to the present-day (0 Ma) land surface shown in Figure 7. To calculate erosion, the $0 \mathrm{Ma}$ land surface is subtracted from the $4.5 \mathrm{Ma}$ land surface to obtain the erodible thickness (ET), which is a function of $\mathbf{x}$, that is, $\operatorname{ET}(\mathbf{x})$. This $\operatorname{ET}(\mathbf{x})$ has to be removed from the top of the model from $4.5 \mathrm{Ma}$ to the present. So, we interpolate the $\mathrm{ET}(\mathbf{x})$ with time between the values calculated at $4.5 \mathrm{Ma}$ and $0 \mathrm{~m}$ at $0 \mathrm{Ma}$. These interpolated values of ET( $\mathbf{x})$ are subtracted from the uplifted surfaces of the 3.5, 3, 2, and $0 \mathrm{Ma}$ models to obtain the final surfaces. 




FIGURE 9: Map of potentiometric surface (hydraulic head contour lines in meters) in rocks of Wolfcampian age, after Nelson et al. ([7], Figure 14A). Hydraulic head ranges from less than $366 \mathrm{~m}$ in water wells in northeastern Kansas to greater than $610 \mathrm{~m}$ in oil and gas wells in eastern Colorado and southwestern Nebraska. Dots represent well control. Control data for the hydrologic model were taken along $800 \mathrm{~km}$ line $\mathrm{A}-\mathrm{A}^{\prime}$.



FIGURE 10: Map of potentiometric surface (hydraulic head contour lines in meters) in rocks of Missourian age, after Nelson et al. ([7], Figure 14C). Hydraulic head ranges from less than $244 \mathrm{~m}$ in water wells in Missouri and Oklahoma to greater than $732 \mathrm{~m}$ in oil and gas wells in eastern Colorado. Dots represent well control. Control data for the hydrologic model were taken along $800 \mathrm{~km} \mathrm{line} \mathrm{A-A'.}$ 




FIGURE 11: Map of potentiometric surface (hydraulic head contour lines in meters) in rocks of Mississippian age, after Nelson et al. ([7], Figure 14E). Hydraulic head decreases from about $366 \mathrm{~m}$ in water wells in Missouri and Arkansas to less than $183 \mathrm{~m}$ in oil and gas wells in eastern Oklahoma and then increases westward to values greater than $366 \mathrm{~m}$ in eastern Colorado. Dots represent well control. Control data for the hydrologic model were taken along $800 \mathrm{~km}$ line A-A'.



FIgURE 12: Hydraulic head versus distance digitized from head contours. Hydraulic head for six geohydrologic units along line A-A', which serve as control data for the hydrologic model of this paper. Head values were digitized from potentiometric maps such as those shown in Figures 9, 10, and 11.

The second part of the calibration process includes running the sequence of models using variable rates of flux at the western boundary and variable specific storage $\left(S_{s}\right)$, horizontal hydraulic conductivity $\left(K_{h}\right)$, and vertical hydraulic conductivity $\left(K_{v}\right)$ values, until the calculated present-day hydraulic head values approximated the present-day hydraulic head values. This is described in the next two sections.

3.3.2. Hydraulic Conductivity and Specific Storage. The simulations of the heads, horizontal gradients, and the relation among the hydraulic head profiles displayed in Figure 12 are highly sensitive to hydraulic conductivity $K$, which can vary over many orders of magnitude. We have relied on previous modeling studies (Appendix C) to establish a range of reasonable values of $K$.

For further adjustment of $K$ values, a useful tool is provided by Darcy's equation relating flux $q$ to the hydraulic conductivity $K$ and the hydraulic gradient, $\mathrm{d} h / \mathrm{d} \mathbf{x}$, which aided us during calibration:

$$
q_{h}=-K_{h} \cdot \frac{\mathrm{d} h}{\mathrm{~d} \mathbf{x}}
$$

where $K_{h}$ is the horizontal hydraulic conductivity and $h$ is hydraulic head. Equation (2) indicates that, for a specific $q_{h}, K_{h}$ and $\mathrm{d} h / \mathrm{d} \mathbf{x}$ are inversely proportional. That is, as the medium becomes more conductive and $K$ increases, the hydraulic gradient decreases and the plot of $h$ versus $\mathbf{x}$ becomes shallower or less steep. Conversely, a steep hydraulic gradient indicates a tight or low hydraulic conductivity medium. Based on this, the $K_{h}$ and $K_{v}$ values were varied to make the calculated heads as close to actual values as possible.

The Mississippian geohydrologic unit represents the combined strata of Cambrian-Ordovician-Silurian as well as rocks of Mississippian age. The data (Figure 12) show that 


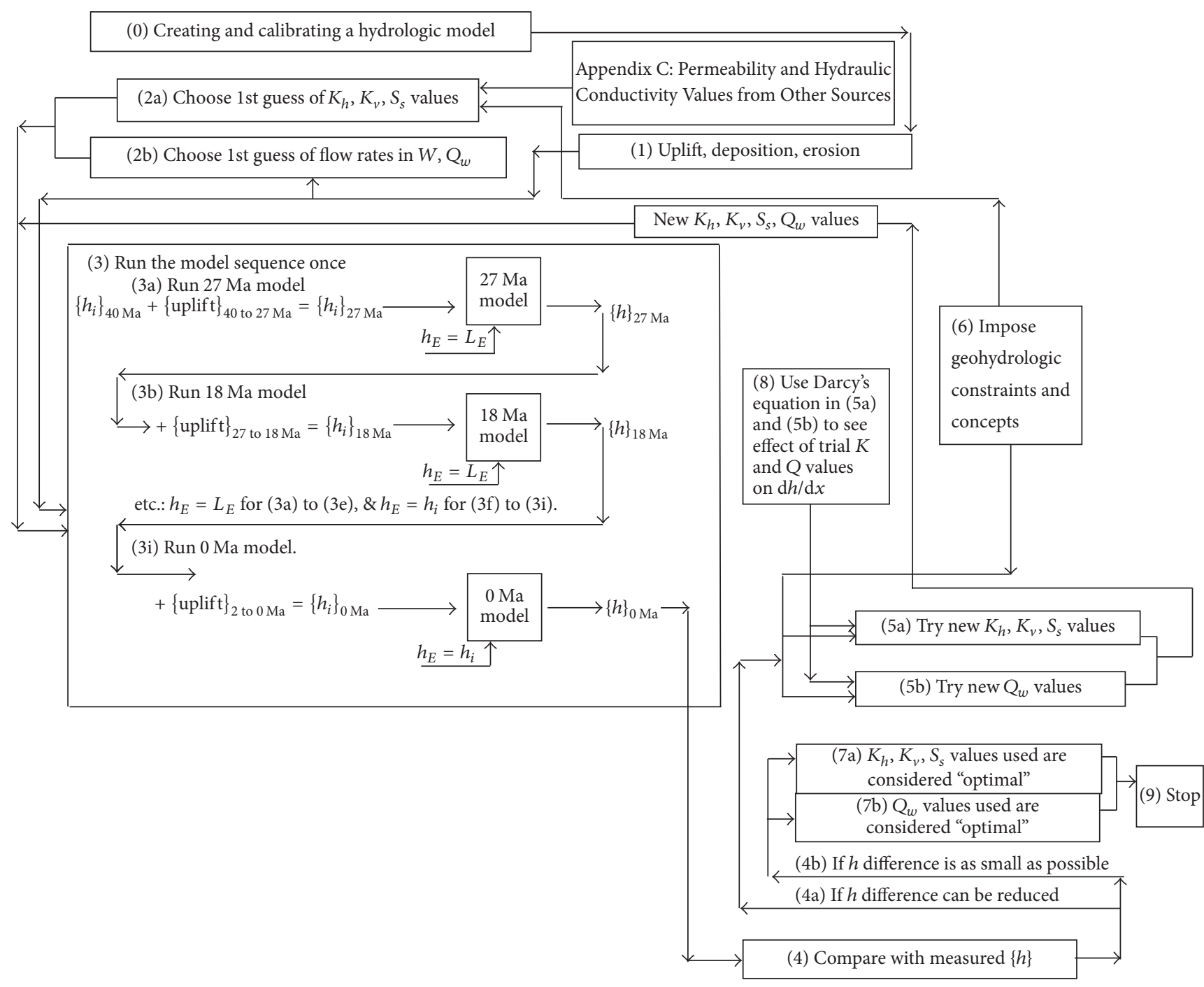

FIGURE 13: Flow chart of the modeling process. $h_{E}$ : head specified in east; $L_{E}$ : Land surface elevation in the east; $h_{i}$ : interpolated $h$ between $\{h\}_{4.5 \mathrm{Ma}}$ and Wolfcampian $h$ contour in $E$ for layers (1) to (7), and between $\{h\}_{4.5 \mathrm{Ma}}$ and Mississippian $h$ contour in $E$ for layers (8) to (10). Box numbers in the figure after step (4) are for labelling and are not strictly sequential.

these lowermost units must be considerably more permeable (shallow hydraulic gradient) than the Virgilian-Missourian and Wolfcampian units (steeper hydraulic gradient) and, based on the separation of the hydraulic head values, must be hydraulically isolated. Hydraulic isolation is achieved by assigning low vertical permeability in the Desmoinesian and basal Pennsylvanian units. Permeability normal to bedding is generally considerably less than parallel to bedding. Consequently, we set $K_{v}=K_{h} / 10$ in most of the geohydrologic units (Table 5), a selection that is the default setting in MODFLOW. However, $K_{v}$ was set to $2 \times 10^{-10} \mathrm{~m} \mathrm{~d}^{-1}$ in the lowermost three layers to provide vertical isolation and to prevent leakage into underlying basement rocks. If the vertical hydraulic conductivity, $K_{v}$, is large, the hydraulic head plots of $h$ versus $\mathbf{x}$ for the 10 layers of the model tend to overlie each other. In order to articulate different behaviors in the vertically stacked 10 layers, vertical isolation, or low $K_{v}$, is needed.
The $K_{h}$ values for the Mississippian geohydrologic unit range from $10^{-4}$ to $10^{-1} \mathrm{~m} \mathrm{~d}^{-1}$ within the upper part of the distribution shown in Figure 18, as described in Signor et al. [16]. After some experimentation, $K_{h}$ for the Mississippian geohydrologic unit was set to $5 \times 10^{-3} \mathrm{~m} \mathrm{~d}^{-1}$, which falls within the range cited in Signor et al. [16]. Table 5 presents the final $K$ values from the model calibration.

Figure 12 shows an abrupt change in the hydraulic head of the Desmoinesian geohydrologic unit where the hydraulic head values transition from the shallower Wolfcampian-Virgilian-Missourian to the lower Mississippian and CambrianOrdovician-Silurian geohydrologic units. This abrupt change is due to a change in $K_{h}$ of the Desmoinesian geohydrologic unit. The model assigns a $K_{h}$ value of $1 \times 10^{-9} \mathrm{~m} \mathrm{~d}^{-1}$ for the western section of the Desmoinesian and a $K_{h}$ value of $5 \times 10^{-3} \mathrm{~m} \mathrm{~d}^{-1}$ for the eastern section (Table 5). This, combined with vertical isolation, enabled us to simulate how 
TABLE 1: Correlation of sections of the paper with FE elements of the flow chart of the modeling process in Figure 13 that they refer to.

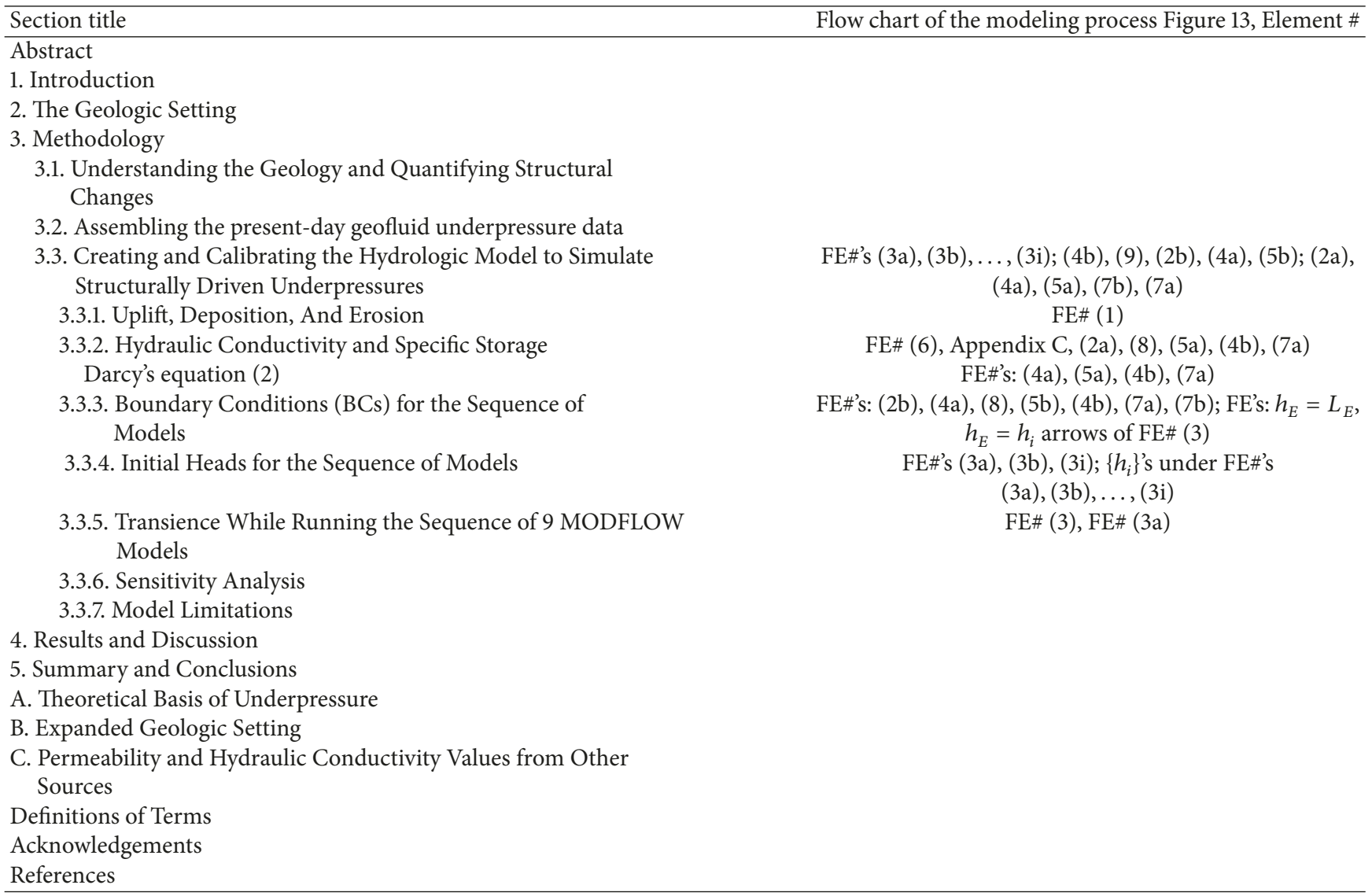

the Desmoinesian head plot resembles the WolfcampianVirgilian-Missourian head plots in the west and the Mississippian plot in the east in the present-day head data.

Two geohydrologic units-Virgilian-Missourian and Wolfcampian-exhibit small changes in slope of the hydraulic head at a distance of $400 \mathrm{~km}$. To replicate these transitions in the Virgilian-Missourian and Wolfcampian, lowpermeability segments referred to as chokes are inserted in the model. Within the chokes, $K_{h}$ is one-fifth that of $K_{h}$ on either side of the choke (Table 5). The low-permeability chokes may represent losses or discontinuities in largescale hydraulic continuity resulting from the transition from mainly marine deposition in the east to exclusively terrestrial deposition in the west in upper Paleozoic rocks. The hydraulic conductivity of $5 \times 10^{-4} \mathrm{~m} \mathrm{~d}^{-1}$ representing the permeable sections of the Virgilian-Missourian and Wolfcampian units is about one-tenth that of values found throughout Kansas in strata of Pennsylvanian-Jurassic age (Figure 18) and is onetwentieth of the value of $10^{-2} \mathrm{~m} \mathrm{~d}^{-1}$ used for shelf carbonates in the Palo Duro Basin (Figure 19).

$K_{h}$ of the upper five geohydrologic units was set to a low value of $1 \times 10^{-6} \mathrm{~m} \mathrm{~d}^{-1}$. This choice is reasonable for the Upper Cretaceous Pierre Shale and Upper Permian-Jurassic units and does assure isolation of the lower units from land surface. However, it is unrealistic for the permeable Upper Cretaceous Dakota Formation, which was not modeled in this study. The broad horseshoe shape of the Dakota outcrop is difficult to model with a two-dimensional grid, and potentiometric maps indicate that the Dakota is not hydraulically connected to the Wolfcampian because of the presence of the low-permeability Upper Permian-Jurassic unit [7].

For the storage characteristics (compressibility of the medium and fluid), a specific storage, $S_{s}$, value of $1 \times 10^{-6} \mathrm{~m}^{-1}$ was used throughout the model. The storage coefficient, $S$, was calculated as $S_{s} \times$ layer thickness.

3.3.3. Boundary Conditions (BCs) for the Sequence of Models. The models' western boundary is defined by the Rocky Mountain Front. It is modeled as a specified-flux boundary to represent flow from the west across the Golden Fault. By altering the flux until the head gradient matched the data (Darcy's equation (2) shows that there is a direct relationship between flux and hydraulic gradient), it was found that $0.0003 \mathrm{~m}^{3} \mathrm{~d}^{-1}$ of water $\left(109,500 \mathrm{~m}^{3}\right.$ per $1 \mathrm{~m} . \mathrm{y}$.) enters each of the Wolfcampian (cross-sectional area $15,239 \mathrm{~m}^{2}$ ) and Desmoinesian (cross-sectional area $18,287 \mathrm{~m}^{2}$ ) and 0.0007 $\mathrm{m}^{3} \mathrm{~d}^{-1}$ (255,500 $\mathrm{m}^{3}$ per $\left.1 \mathrm{~m} . \mathrm{y}.\right)$ of water enters the VirgilianMissourian (cross-sectional area $33,526 \mathrm{~m}^{2}$ ). These values were applied throughout the modeling sequence.

It should be noted that when the amount of specified flow rate into the western boundary, $Q_{w}$, or flux, $q_{w}$, is increased, the hydraulic head in the geohydrologic unit receiving the 
TABLE 2: Stratigraphic column.

\begin{tabular}{|c|c|c|c|c|c|}
\hline Age & $\begin{array}{l}\text { Geohydrologic unit } \\
\text { name }\end{array}$ & Lithologic description & $\begin{array}{c}\text { Geohydrologic unit } \\
\text { type }\end{array}$ & Model layer & $\begin{array}{l}\text { Range of thickness } \\
\text { (feet) }\end{array}$ \\
\hline Neogene & Ogallala Formation & $\begin{array}{c}\text { Terrestrial gravel, } \\
\text { sand, and clay }\end{array}$ & Aquifer & 1 & $0-300$ \\
\hline Neogene-Paleogene & Laramide Basin Fill & $\begin{array}{c}\text { Terrestrial gravel, } \\
\text { sand, and clay }\end{array}$ & Aquifer & 2 & $0-2,300$ \\
\hline Late Cretaceous & $\begin{array}{l}\text { Pierre \& Niobrara } \\
\text { Formations }\end{array}$ & $\begin{array}{c}\text { Marine shales and } \\
\text { carbonates, some } \\
\text { sand layers }\end{array}$ & Aquitard & 3 & $0-6,800$ \\
\hline Early Cretaceous & Dakota Formation & Sandstone & Aquifer & 4 & $0-500$ \\
\hline $\begin{array}{l}\text { Jurassic-Triassic-late } \\
\text { Permian }\end{array}$ & $\begin{array}{l}\text { Morrison-Leonardian } \\
\text { Formations }\end{array}$ & $\begin{array}{c}\text { Terrestrial sand, silt, } \\
\text { and clay with upper } \\
\text { Permian shale and } \\
\text { evaporites }\end{array}$ & Aquitard & 5 & $0-1,200$ \\
\hline Early Permian & $\begin{array}{l}\text { Wolfcampian } \\
\text { Formation }\end{array}$ & $\begin{array}{l}\text { Clastic marine } \\
\text { sediments with } \\
\text { carbonate beds }\end{array}$ & Aquifer & 6 & $0-1,100$ \\
\hline Pennsylvanian & $\begin{array}{l}\text { Virgilian-Missourian } \\
\text { Formation }\end{array}$ & $\begin{array}{l}\text { Clastic marine } \\
\text { sediments with } \\
\text { carbonate beds }\end{array}$ & Aquifer & 7 & $400-1,600$ \\
\hline Pennsylvanian & $\begin{array}{l}\text { Desmoinesian } \\
\text { Formation }\end{array}$ & $\begin{array}{l}\text { Marine carbonates in } \\
\text { the east, terrestrial } \\
\text { sediments in the west }\end{array}$ & $\begin{array}{l}\text { Aquitard in west, } \\
\text { aquifer in east }\end{array}$ & 8 & $100-700$ \\
\hline Early Pennsylvanian & $\begin{array}{c}\text { Basal Pennsylvanian } \\
\text { Unit }\end{array}$ & $\begin{array}{l}\text { Marine shales with } \\
\text { some carbonates }\end{array}$ & Aquitard & 9 & 100 \\
\hline Early Paleozoic & $\begin{array}{c}\text { Mississippian- } \\
\text { Silurian-Ordovician- } \\
\text { Cambrian } \\
\text { Units }\end{array}$ & $\begin{array}{l}\text { Limestones and } \\
\text { dolomites with karst } \\
\text { weathering, \& lesser } \\
\text { interbedded shales }\end{array}$ & Aquifer & 10 & $0-1,100$ \\
\hline Precambrian & $\begin{array}{c}\text { Precambrian } \\
\text { Basement }\end{array}$ & Granite and gneiss & No-flow boundary & $\begin{array}{c}\text { Model lower } \\
\text { boundary }\end{array}$ & NA \\
\hline
\end{tabular}

TABLE 3: The sequence of nine MODFLOW Models (m.y.: million years).

\begin{tabular}{|c|c|c|c|c|}
\hline $\begin{array}{l}\text { Sequence number of } \\
\text { each model }\end{array}$ & Name of model & Time span (Ma) & $\begin{array}{c}\text { Number of years } \\
\text { modeled (m.y.) }\end{array}$ & $\begin{array}{l}\text { Figure number showing } \\
\text { grid }\end{array}$ \\
\hline First & $27 \mathrm{Ma}$ & 40 to $27 \mathrm{Ma}$ & 13 & Figure 14 \\
\hline Second & $18 \mathrm{Ma}$ & 27 to $18 \mathrm{Ma}$ & 9 & Figure 15 \\
\hline Third & $11 \mathrm{Ma}$ & 18 to $11 \mathrm{Ma}$ & 7 & None \\
\hline Fourth & $7 \mathrm{Ma}$ & 11 to $7 \mathrm{Ma}$ & 4 & None \\
\hline Fifth & $4.5 \mathrm{Ma}$ & 7 to $4.5 \mathrm{Ma}$ & 2.5 & Figure 16 \\
\hline Sixth & $3.5 \mathrm{Ma}$ & 4.5 to $3.5 \mathrm{Ma}$ & 1 & None \\
\hline Seventh & $3 \mathrm{Ma}$ & 3.5 to $3 \mathrm{Ma}$ & 0.5 & None \\
\hline Eighth & $2 \mathrm{Ma}$ & 3 to $2 \mathrm{Ma}$ & 1 & None \\
\hline Ninth & $0 \mathrm{Ma}$ & 2 to $0 \mathrm{Ma}$ & 2 & Figure 7 \\
\hline
\end{tabular}

flux increases and the plot of head versus $\mathbf{x}$ becomes steeper in the west (based on Darcy's equation (2)). The optimal values of flux $(q)$ obtained by the calibration process were used as the western BCs for the sequence of models.

The models' eastern boundary lies in east-central Kansas (Figures 2 and 6), where the confined units crop out and all layers are exposed to the atmosphere. From the definition of the hydraulic head, $h$, in (A.1), we see that when the pressure is atmospheric, $p$ becomes 0 and $h=z$. So, for units exposed to the atmosphere in the east, the hydraulic head is equal to the land elevation. Consequently, the eastern BC for the 27, 18, 11,7 , and 4.5 Ma models of the sequence is a constant head $\mathrm{BC}$ set equal to the land elevation for these models in the east (see $h_{E}=L_{E}$ arrows in Figure 13). The same constant head BC $(h=z)$ in the east was set for all layers in the model, which implies hydrostatic conditions at the eastern boundary.

However, for the 3.5, 3, 2, and 0 Ma models, the eastern $\mathrm{BC}$ values were calculated by interpolation between the 4.5 


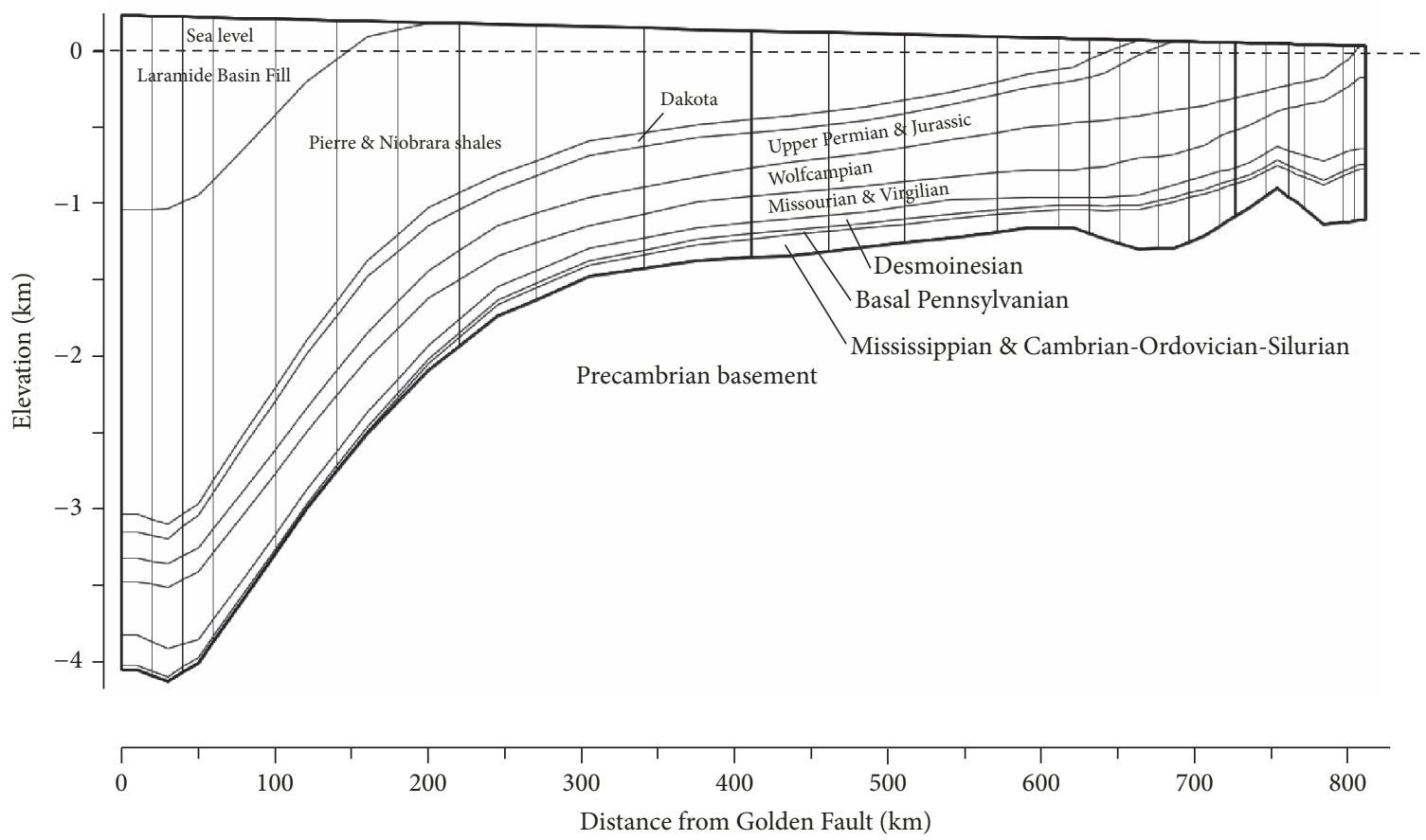

FIGURE 14: Grid of the first model of the sequence, having the geometry at $27 \mathrm{Ma}$, used to model the period from 40 to $27 \mathrm{Ma}$.

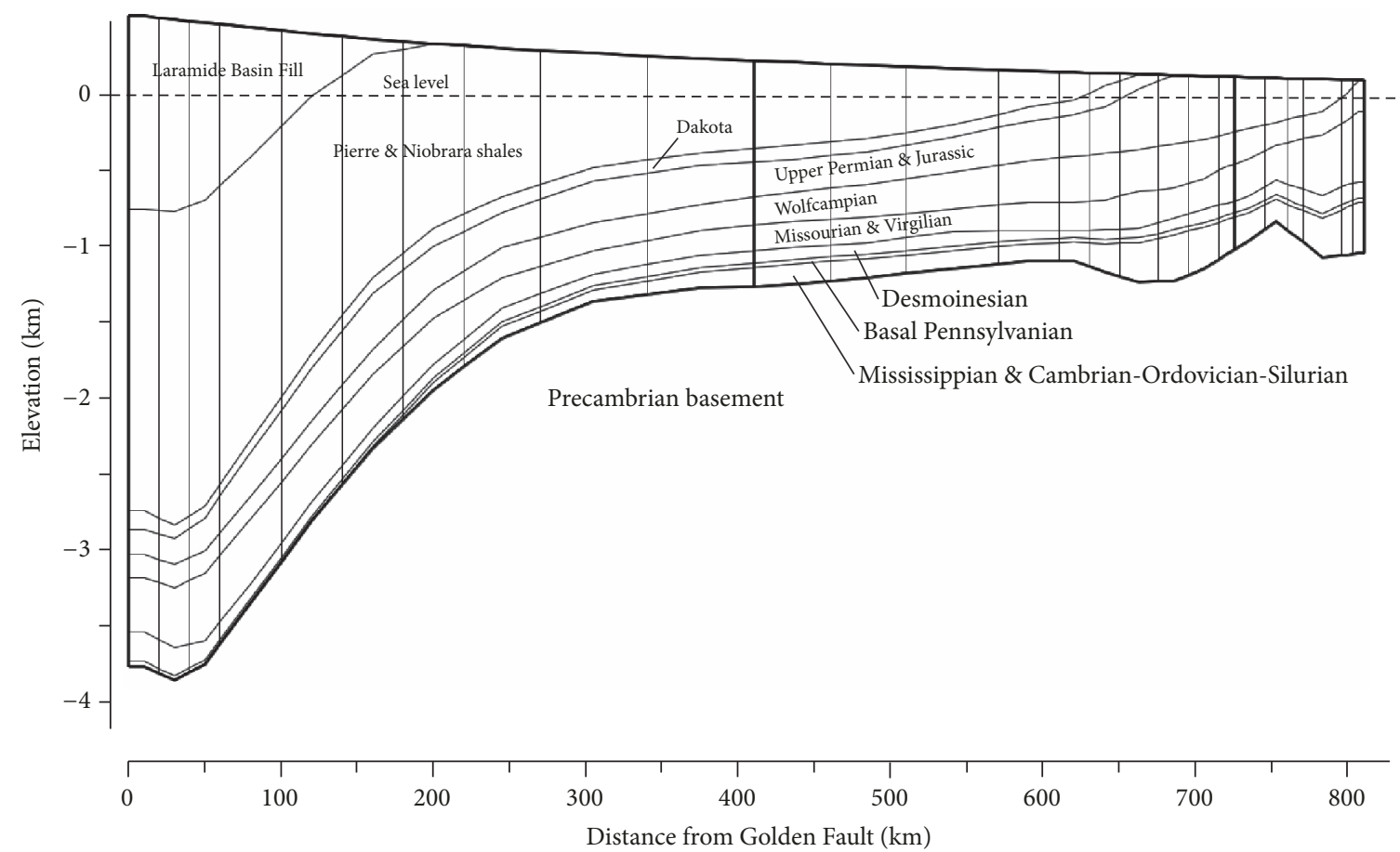

FIGURE 15: Grid of the second model of the sequence, having the geometry at $18 \mathrm{Ma}$, used to model the period from 27 to $18 \mathrm{Ma}$.

Ma model hydraulic head values and present-day hydraulic head values obtained from potentiometric surface maps of the Wolfcampian and Mississippian (Figures 9 and 11; [7]); see $h_{E}=h_{i}$ arrows in Figure 13. The Wolfcampian at the east end of the model crops out at a land surface elevation of about $305 \mathrm{~m}$ ([7], Figure 14A).
The Wolfcampian head is, therefore, fixed to $C_{\mathrm{WE}}$ of $305 \mathrm{~m}$ in the last column of the model in the east at $0 \mathrm{Ma}$. Wolfcampian head values were then interpolated between $304.785 \mathrm{~m}$ and the Wolfcampian head of $310.906 \mathrm{~m}$ in the easternmost column calculated at $4.5 \mathrm{Ma}$ by the $4.5 \mathrm{Ma}$ model. These intermediate temporally interpolated values, $h_{i}$, 




FigurE 16: Grid of the fifth model of the sequence, having the geometry at $4.5 \mathrm{Ma}$, of maximum deposition, used to model the period from 7 to $4.5 \mathrm{Ma}$. The vertically expanded part of section from 200 to $600 \mathrm{~km}$ in the inset shows details of horizontal hydraulic conductivity structure.

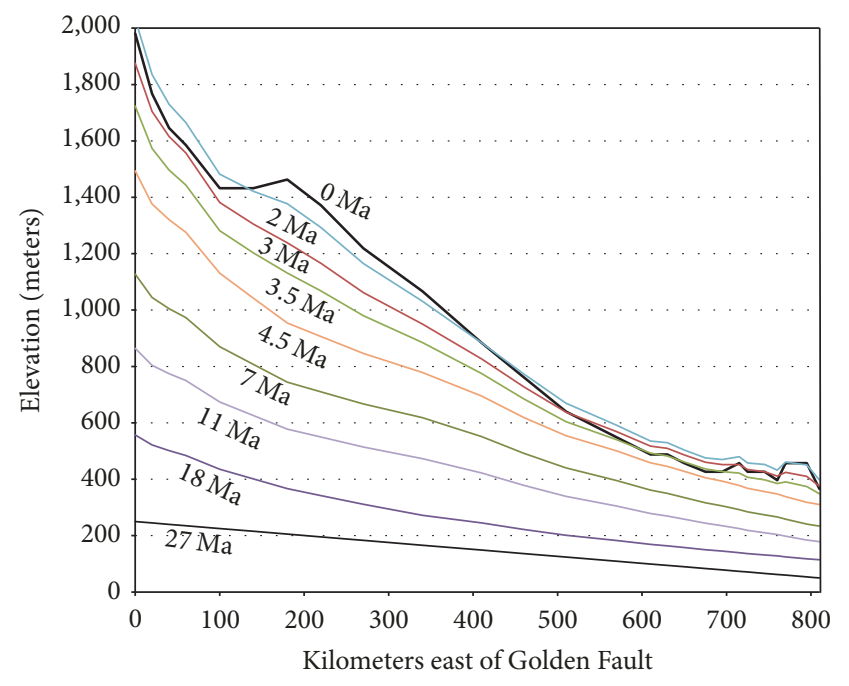

FIGURE 17: Stacked land surfaces of the 9 MODFLOW models showing progressive uplift from $27 \mathrm{Ma}$ to $0 \mathrm{Ma}$.

of the Wolfcampian heads at $3.5 \mathrm{Ma}, 3 \mathrm{Ma}$, and $2 \mathrm{Ma}$ were then used to set the constant head $\mathrm{BC}$ in the east for the Wolfcampian unit for the 3.5, 3, 2, and 0 Ma models. These same interpolated values of the Wolfcampian heads were used to set the constant head BC in the east for the top seven layers (which include the Wolfcampian as layer (6), Table 2) of the $3.5,3,2$, and $0 \mathrm{Ma}$ models, assuming equal heads in these layers.

The eastern BC for the bottom 3 layers in the $3.5,3,2$, and 0 Ma models was established in a similar fashion, as $h_{E}=h_{i}$, but with $h_{i}$ using calculated and actual contoured $h$ values of the Mississippian instead of the Wolfcampian, with a $C_{\mathrm{ME}}$ value of $183 \mathrm{~m}$ at $0 \mathrm{Ma}$, based on contoured values of Figure 11 .

It should be noted that when the head is fixed to a specific value at the eastern boundary, MODFLOW varies the flux at the boundary, as needed, to maintain the specified head value, according to Darcy's equation (see (2)). This affects the head gradient terminating at the boundary.

The values of specified flow rate in the west, $Q_{w}, S_{s}$, and $K\left(K_{h}\right.$ and $\left.K_{v}\right)$, resulting in calculated present-day hydraulic head values closest to the actual present-day hydraulic head values, are referred to as "optimal" values. Even though we refer to these values as "optimal," it should be noted that this solution is not unique, and other combinations of $Q_{w}$, $S_{s}$, and $K$ values could have produced calculated present-day hydraulic head values as close, or closer, to the actual presentday hydraulic head values. The "optimal" $Q_{w}, S_{s}$, and $K\left(K_{h}\right.$ and $K_{v}$ ) values were used in obtaining the final modeling results presented in this paper.

The sensitivity of the calculated $h$ values to assumed flux $\left(q_{w}\right), S_{s}$, and $K\left(K_{h}\right.$ and $\left.K_{v}\right)$ values are presented in Sensitivity Analysis.

3.3.4. Initial Heads for the Sequence of Models. The initial heads at $70 \mathrm{Ma}$, prior to any uplift, represent the hydrostatic head of the Cretaceous Western Interior Seaway that was assumed to overlie most of the study area. That hydrostatic head is $0 \mathrm{~m}$ if we take mean sea level to be the vertical datum.

As was presented earlier, hydraulic head $(h)$, in units of $\mathrm{L}$, is given as shown in (A.1). 
TABLE 4: Percent and cumulative percent of total uplift, relative to $27 \mathrm{Ma}$, for the 9 MODFLOW model times.

\begin{tabular}{lcc}
\hline Geologic time & $\begin{array}{c}\text { Cumulative percent of total uplift at mountain } \\
\text { front (assumed constant for all } \mathbf{x}) \text { (CpTU) }\end{array}$ & Percent of total uplift (PTU) \\
\hline $27 \mathrm{Ma}$ & 13.125 & 13.125 \\
$18 \mathrm{Ma}$ & 26.250 & 13.125 \\
$11 \mathrm{Ma}$ & 37.500 & 15.6250 \\
$7 \mathrm{Ma}$ & & 15.625 \\
$4.5 \mathrm{Ma}$ & 53.125 & 9.375 \\
$3.5 \mathrm{Ma}$ & 68.750 & 12.500 \\
$3 \mathrm{Ma}$ & 78.125 & 9.375 \\
$2 \mathrm{Ma}$ & 90.625 & 100 \\
\hline
\end{tabular}

TABLE 5: Hydraulic conductivities of the (10) geohydrologic units (layers) of each model in the sequence. Hydraulic conductivities in meters per day $\left(\mathrm{m} \mathrm{d}^{-1}\right)$. In units (1)-(7), the vertical hydraulic conductivity $K_{v}$ is set to one-tenth the value of the horizontal hydraulic conductivity $K_{h}$. In units (6) and (7), a low- $K$ choke separates more permeable units in the west and east. In unit (8), $K$ is higher in the east than in the west.

\begin{tabular}{|c|c|c|}
\hline Geohydrologic unit & $K_{h}\left(\mathrm{~m} \mathrm{~d}^{-1}\right)$ & $K_{v}\left(\mathrm{~m} \mathrm{~d}^{-1}\right)$ \\
\hline (1) Ogallala & $1 \times 10^{-6}$ & $K_{h} / 10$ \\
\hline (2) Tertiary sediments & $1 \times 10^{-6}$ & $K_{h} / 10$ \\
\hline (3) Pierre & $1 \times 10^{-6}$ & $K_{h} / 10$ \\
\hline (4) Dakota & $1 \times 10^{-6}$ & $K_{h} / 10$ \\
\hline \multirow[t]{2}{*}{ (5) Morrison-Leonardian } & $1 \times 10^{-6}$ & $K_{h} / 10$ \\
\hline & West Choke & \\
\hline (6) Wolfcampian-choke from 407 to $482 \mathrm{~km}$ & $5 \times 10^{-4} \quad 1 \times 10^{-4} \quad 5 \times 10^{-4}$ & $K_{h} / 10$ \\
\hline (7) Virgilian-Missourian-choke from 375 to $393 \mathrm{~km}$ & $5 \times 10^{-4} \quad 1 \times 10^{-4} \quad 5 \times 10^{-4}$ & $K_{h} / 10$ \\
\hline \multicolumn{3}{|l|}{ (8) Desmoinesian } \\
\hline Low $K$ west of $315 \mathrm{~km}$ & $1 \times 10^{-9}$ west of $315 \mathrm{~km}$ & $2 \times 10^{-10}$ \\
\hline High $K$ east of $315 \mathrm{~km}$ & $5 \times 10^{-3}$ east of $315 \mathrm{~km}$ & $2 \times 10^{-10}$ \\
\hline (9) Basal Pennsylvanian & $1 \times 10^{-9}$ & $2 \times 10^{-10}$ \\
\hline (10) Mississippian & $5 \times 10^{-3}$ & $2 \times 10^{-10}$ \\
\hline
\end{tabular}

It can be seen from (A.1) and Figure 1 that, in the aquifer at $70 \mathrm{Ma}$, which is saturated by the sea up to its top, $h$ at the top is 0 because $p=0$ (no water above it) and $z=0$ (the aquifer top is defined as sea level, the datum specifically for the purpose of the discussion in this section). For a point in the aquifer at a depth $D, p / \gamma=D$ and $z=-D$; therefore, $h=D-D=0$. So, the initial hydraulic head $h$ is 0 everywhere in the aquifer at $70 \mathrm{Ma}$ and is taken to represent mean sea level. Referring to the $h$ values at all the cells in the model symbolically as the "vector" $\{h\}$, we can say that $\{h\}_{i}=\{0\}$, where $i$ means "initial."

The land surface for the first model, the $27 \mathrm{Ma}$ model shown in Figure 14 used to model the 13-million-year period from 40 to $27 \mathrm{Ma}$, is raised $250 \mathrm{~m}$ ASL in the west (to accommodate the Florissant fossil data) and $50 \mathrm{~m}$ ASL in the east, relative to the Cretaceous Western Interior Seaway. We assume that, at modeling time 0 years $(40 \mathrm{Ma})$, there is a sudden (instantaneous) uplift in the west of $250 \mathrm{~m}$ and in the east of $50 \mathrm{~m}$. According to (A.1), $z$ will be increased by $250 \mathrm{~m}$ in the west, decreasing linearly to $50 \mathrm{~m}$ in the east. Therefore, the initial $\{h\}$ at modeling time 0 years $(40 \mathrm{Ma})$ is $\{0$ from the initial heads in the aquifer at $70 \mathrm{Ma}\}+\{$ Linearly decreasing values from $250 \mathrm{~m}$ in the west to $50 \mathrm{~m}$ in the east $\}$. The $h$ values are the same in all cells of the same column but decrease from $250 \mathrm{~m}$ for column 1 in the west to $0 \mathrm{~m}$ for column 26 in the east. 


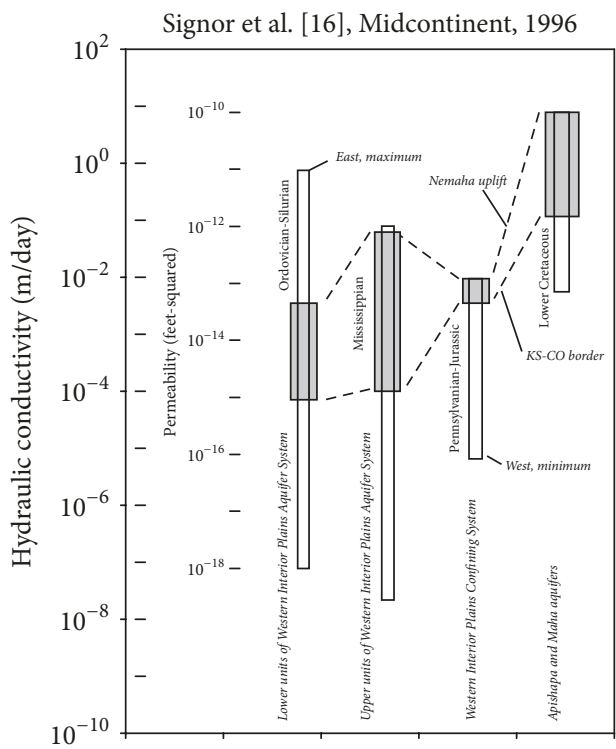

FIgURE 18: Hydraulic conductivity values used by Signor et al. [16] Permeability values in square feet from four maps by Signor et al. [16] for hydrologic units in a study of the Great Plains of the United States. Mapped values increase from west to east, indicated by the open bars. Values between the Kansas/Colorado border and the Nemaha uplift lie within the solid (shaded) bars. Names of hydrologic units used by Signor et al. appear vertically in italics; equivalent names used in this paper appear vertically in normal font. Scale for hydraulic conductivity units $\left(\mathrm{m} \mathrm{d}^{-1}\right)$ used in this paper appears at left, using a conversion of $1 \mathrm{~m} \mathrm{~d}^{-1}=1.19 \times 10^{-12} \mathrm{~m}^{2}$. Values given by Signor and others are permeability in $\mathrm{ft}$-squared, taken from maps (Figures 21, 22, 29, and 36 in Signor et al. [16]). Porosity values from geophysical logs were used to compute permeability estimates using the Kozeny-Carman equation. Conversion used is $K(\mathrm{~m} / \mathrm{d})=1.28 \mathrm{E}-11 \times k(\mathrm{ft}$-squared $)$, at standard temperature and pressure.

With these initial head $\{h\}$ values at $40 \mathrm{Ma}$, as described above, and the boundary conditions and $K$ and $S$ parameters presented earlier, MODFLOW calculates $\{h\}$ for each of the 13 million years ( 40 to $27 \mathrm{Ma}$ ) that the first model, the $27 \mathrm{Ma}$ model, represents, ending at $27 \mathrm{Ma}$ with $\{h\}_{27 \mathrm{Ma}}$.

For the 18 Ma model shown in Figure 15, a sudden (instantaneous) additional rise, $z$, equal to the uplift from 27 to $18 \mathrm{Ma}$, Uplift $\mathrm{27-18 \textrm {Ma }}$, takes place along the length of the model, at $27 \mathrm{Ma}$, creating an equal rise in $h$, according to (A.1). The incremented $\{h\}$ values, $\{h\}_{27 \mathrm{Ma}}+$ Uplift $_{27-18 \mathrm{Ma}}$, represent the initial head values for the $18 \mathrm{Ma}$ model at $27 \mathrm{Ma}$.

With the above initial head values for the $18 \mathrm{Ma}$ model, $\{h\}_{27 \mathrm{Ma}}+\mathrm{Uplift}_{27-18 \mathrm{Ma}}$, at $27 \mathrm{Ma}$, and the boundary condition presented earlier, MODFLOW calculates $\{h\}$ for each of the 9 million years from 27 to $18 \mathrm{Ma}$ that the $18 \mathrm{Ma}$ model represents, ending at $18 \mathrm{Ma}$ with $\{h\}_{18 \mathrm{Ma}}$. The above process is repeated until MODFLOW calculates $\{h\}_{0}$, present-day values at $0 \mathrm{Ma}$. In each time step, MODFLOW calculates the response to a step-function increase in head imposed at the beginning of that time step. Models. When running the first of the 9 MODFLOW models,

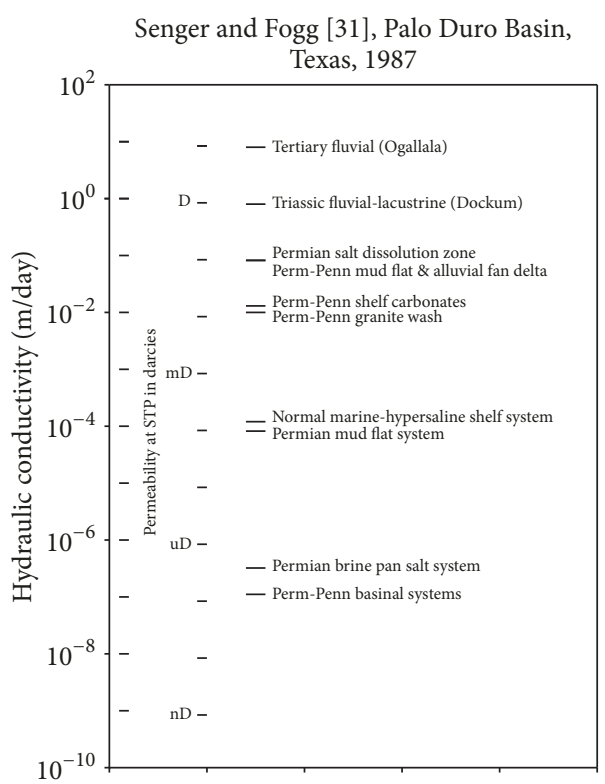

Figure 19: Permeability values selected by Senger and Fogg [31] for hydrologic units in a study of the Palo Duro Basin, Texas. Values range over seven orders of magnitude, from one darcy (D) to 0.1 microdarcies $(\mathrm{uD})$. The left axis label shows equivalents for hydraulic conductivity in $\mathrm{m} \mathrm{d}^{-1}$ using a conversion factor of $1 \mathrm{D}=0.835 \mathrm{~m} \mathrm{~d}^{-1}$. STP, standard temperature and pressure; Perm-Penn, PermianPennsylvanian. The ratio of vertical to horizontal permeability $k_{v} / k_{h}$ ranges from 0.01 to 1.0 .

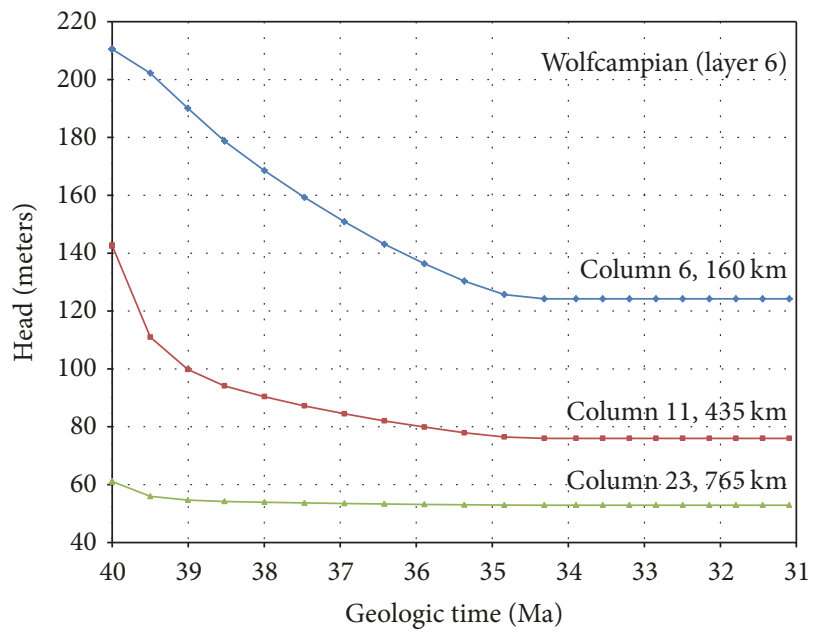

FIgUre 20: Head versus time for Wolfcampian cells in columns 6, 11 , and 23 of the $27 \mathrm{Ma}$ model, showing that steady state is reached around $34.5 \mathrm{Ma}$, after 5.5 million years of simulated time. Head in meters above sea level for Figures 20-33.

the $27 \mathrm{Ma}$ model representing the 13-million-year period from 40 to $27 \mathrm{Ma}$, the transient solution at $30 \mathrm{Ma}$ was close enough to the steady-state solution (which was calculated separately) that the $30 \mathrm{Ma}$ transient solution was considered the final solution for the $27 \mathrm{Ma}$ model. Figure 20 shows that the $27 \mathrm{Ma}$ model solution (in the Wolfcampian) is largely at steady state at approximately $34.5 \mathrm{Ma}$ (5.5 million years of 


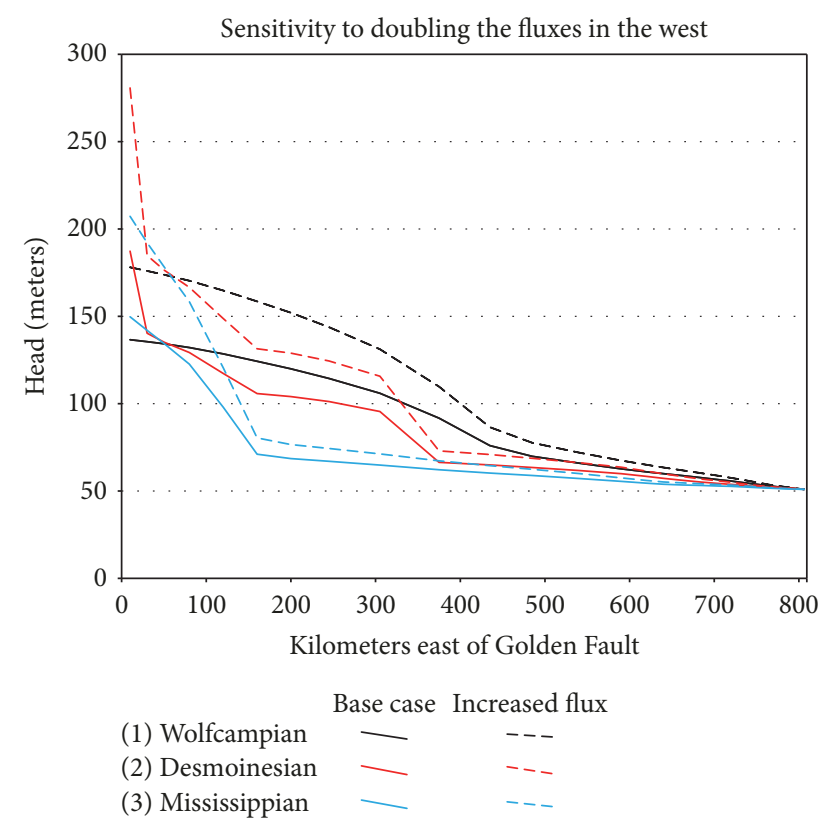

FIGURE 21: Sensitivity to doubling the flux in the west.

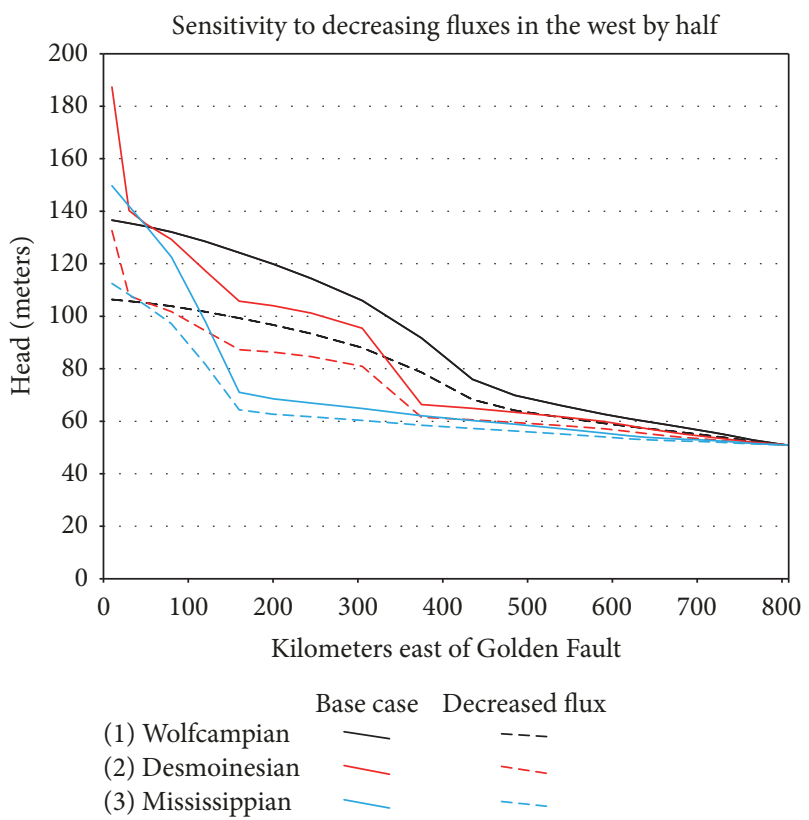

FIGURE 22: Sensitivity to decreasing the flux in the west by one-half.

modeled time from $40 \mathrm{Ma}$ ). This modeled duration to steady state is bracketed by the analytic solution given in Carslaw and Jaeger ([17], Eq. 3.3.14) and presented in Table 6. Because $K$ of the Wolfcampian, from Table 5 , varies between $1 \times 10^{-4}$ and $5 \times 10^{-4} \mathrm{~m} / \mathrm{d}$, the analytic solution indicates from Table 6 that the decay time until steady state is between 14.9 and 1.49 million years.

The remaining 8 MODFLOW models, the $18,11,7,4.5,3.5$, 3,2 , and 0 Ma models, were run for their full durations of 9,7 , $4,2.5,1,0.5,1$, and 2 million years, respectively (see Table 3 ), whether they reached steady state or not. The models with longer modeling periods, specifically the $18,11,7$, and $4.5 \mathrm{Ma}$

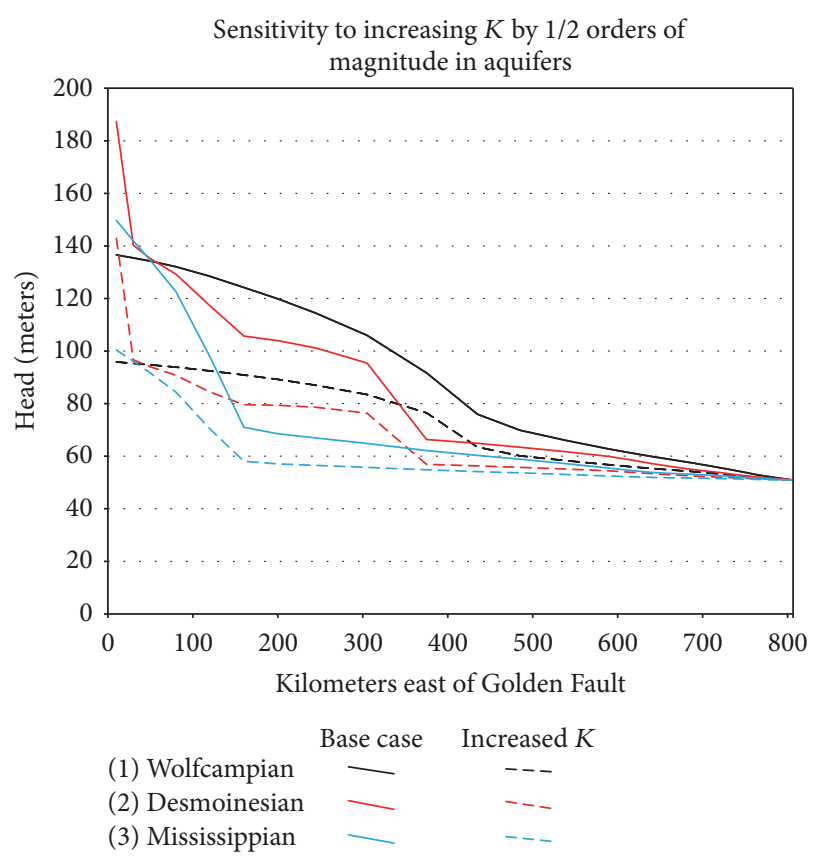

FIGURE 23: Sensitivity to increasing $K$ by half an order of magnitude in aquifers.



FIGURE 24: Sensitivity to decreasing $K$ by half an order of magnitude in aquifers.

models, reached steady state within their modeling periods. The models with shorter modeling periods, specifically the $3.5,3,2$, and $0 \mathrm{Ma}$ models, did not reach steady state. The hydraulic heads at the end of a modeling period were used to create the initial heads for the following period, as described earlier. It did not matter whether the heads at the end of a modeling period were at steady state or not. 


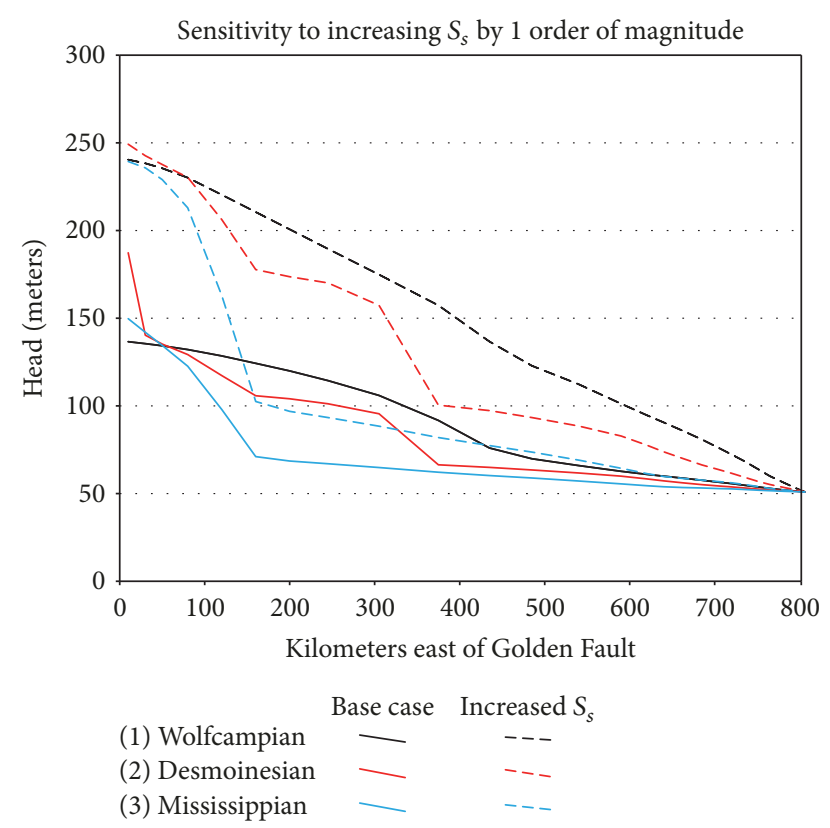

FIgURE 25: Sensitivity to increasing $S_{s}$ by an order of magnitude.

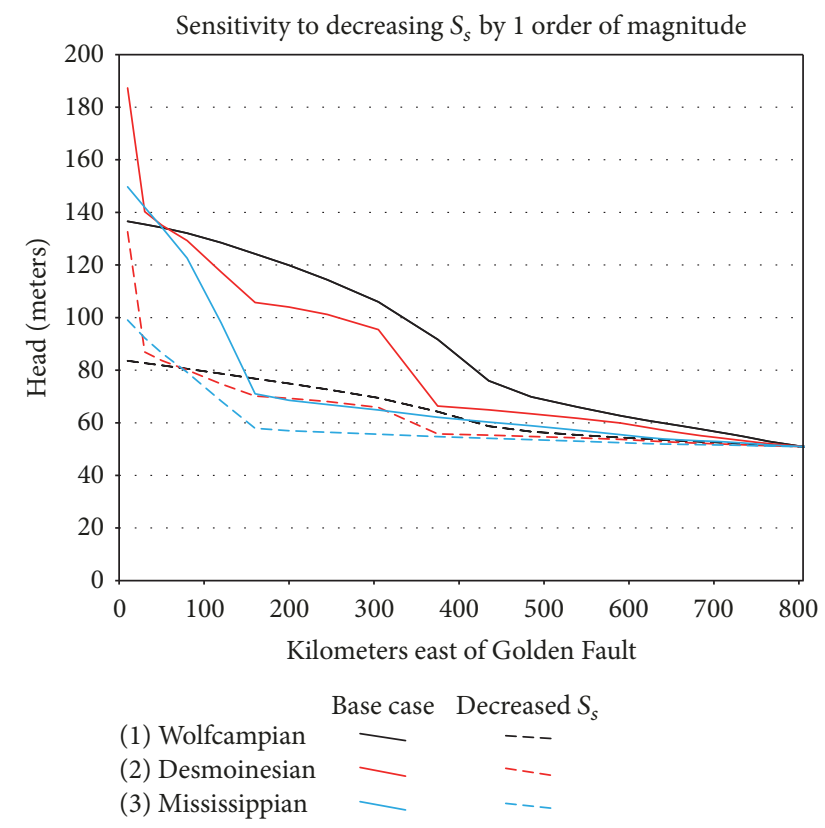

Figure 26: Sensitivity to decreasing $S_{s}$ by an order of magnitude.

3.3.6. Sensitivity Analysis. Using model 1 (40 to $27 \mathrm{Ma}$ ) with optimal parameters as a base case (see Table 5 for values of $K$ ), we computed perturbed $h$ profiles corresponding to perturbed values of flux on the western boundary (Figures 21 and 22). Doubling the flux produces perturbed $h$ values greater than the base case, and halving the flux produces perturbed $h$ values less than the base case. At $x=200 \mathrm{~km}$, the changes in $h$ range from $+5 \mathrm{~m}$ in the Mississippian unit to $+32 \mathrm{~m}$ in the Wolfcampian unit. The relatively low changes in $h$ in the Mississippian unit are due to its westward pinchout and lack of direct hydraulic connection to flux at the



FIGURE 27: Sensitivity to increasing $K$ by 2 orders of magnitude in layers (1), (2), and (4).

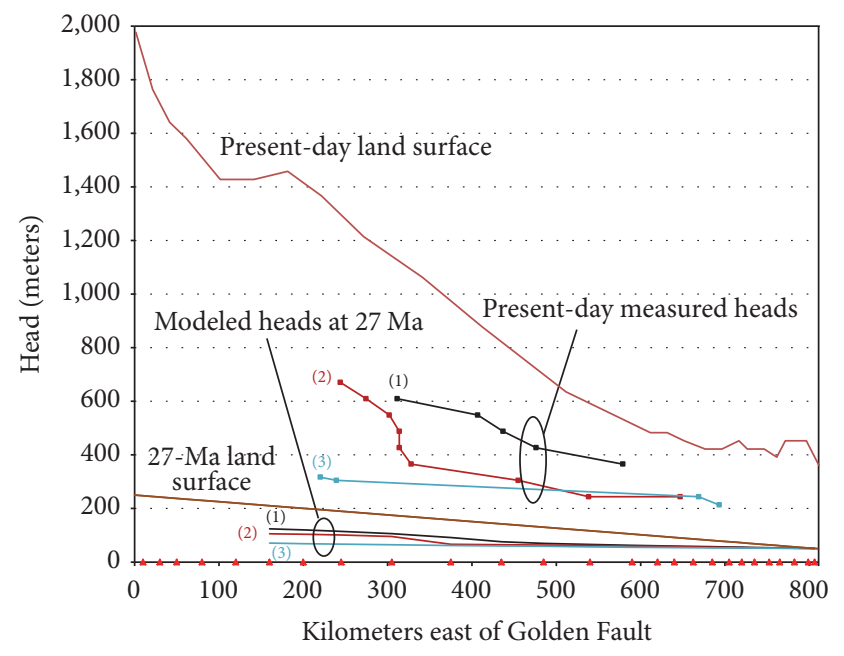

(1) Wolfcampian
(2) Desmoinisian
(3) Mississippian

FIGURE 28: Modeled head results of running the first model, the 27 Ma model representing the 13-million-year period from 40 to $27 \mathrm{Ma}$, compared to present-day heads. Model curves (1), (2), and (3) (Wolfcampian, Desmoinesian, and Mississippian, resp.) eventually approach the present-day data curves. Red triangles at centroids of the grid columns mark the initial zero heads at $70 \mathrm{Ma}$.

western boundary (Figure 7). Perturbations tend to zero at the eastern boundary where the solution is constrained by the constant head boundary condition. The base case flux values determined for the western boundary are quite low: 109,500, 109,500, and 255,500 $\mathrm{m}^{3}$ per million years for the Wolfcampian, Desmoinesian, and Virgilian-Missourian units, respectively. If these fluxes were to penetrate uniformly into a horizontal prism and fill only one percent of rock 


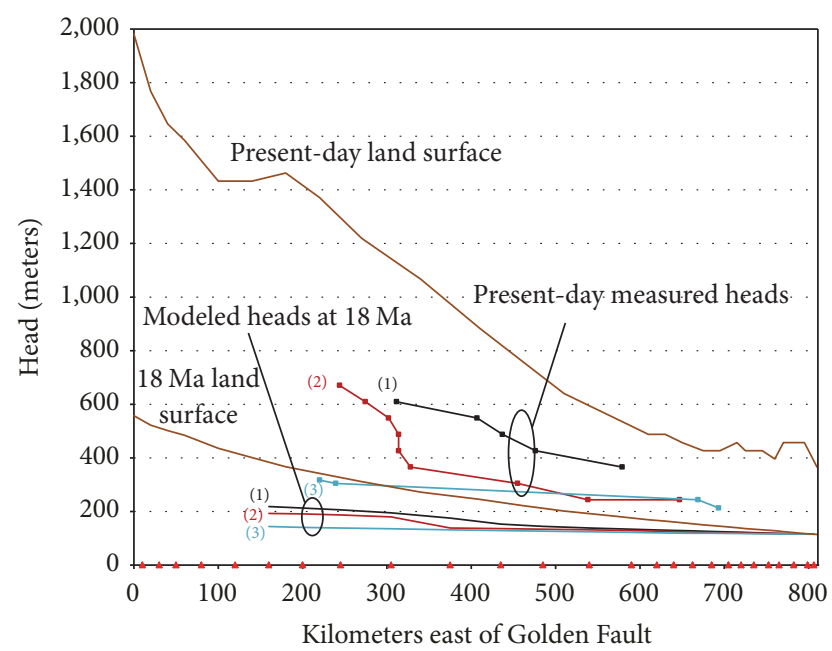

(1) Wolfcampian

(2) Desmoinisian

(3) Mississippian

Figure 29: Results of running the second model, the $18 \mathrm{Ma}$ model, representing the 9-million-year period from 27 to $18 \mathrm{Ma}$, compared to present-day heads. Model curves (1), (2), and (3) (Wolfcampian, Desmoinesian, and Mississippian, resp.) are approaching the present-day data curves. Red triangles at centroids of the grid columns mark the initial zero heads at $70 \mathrm{Ma}$.

TABLE 6: Analytical solution for decay time to steady state in the west as a function of hydraulic conductivity, based on equations in Carslaw and Jaeger [17].

\begin{tabular}{lcc}
\hline$K\left(\mathrm{~m} \mathrm{~d}^{-1}\right)$ & $K\left(\mathrm{~m} \mathrm{~s}^{-1}\right)$ & $\begin{array}{c}\text { Decay time (million } \\
\text { years) }\end{array}$ \\
\hline $1.00 \times 10^{-2}$ & $1.16 \times 10^{-7}$ & 0.149 \\
$1.00 \times 10^{-3}$ & $1.16 \times 10^{-8}$ & 1.49 \\
$1.00 \times 10^{-4}$ & $1.16 \times 10^{-9}$ & 14.9 \\
$1.00 \times 10^{-5}$ & $1.16 \times 10^{-10}$ & 149 \\
$1.00 \times 10^{-6}$ & $1.16 \times 10^{-11}$ & 1,490 \\
\hline
\end{tabular}

volume, the $x$-length of penetration would be 719,599 , and $762 \mathrm{~m}$, or less than one kilometer per million years. In other words, the total penetration, assuming that one percent of rock volume is utilized, would be about 20 to $30 \mathrm{~km}$ for the 40 m.y. duration of flux. Our model suggests that fluxes from the west are of little significance volumetrically even though the rates are highly constrained.

A second concern is the sensitivity of the model to its fixed parameters $K$ and $S_{s}$ (Figures 23-26). The key parameter in (1) is the ratio $K / S_{s}$, suggesting that perturbations in $K$ and $S_{s}$ should produce opposite effects, and this is indeed the case. An increase in $K$ drops $h$ below the base case (Figure 23), and so does a decrease in $S_{s}$ (Figure 26). Conversely, a decrease in $K$ and an increase in $S_{s}$ both produce increases in $h$ (Figures 24 and 25).

A third sensitivity test examines the effect of a much higher $K$ in the uppermost layers of the model (Figure 27). $K$ of Pierre Shale is maintained at $K=10^{-6}$ and the overlying and underlying units are increased to $10^{-4}$. Figure 27 shows that

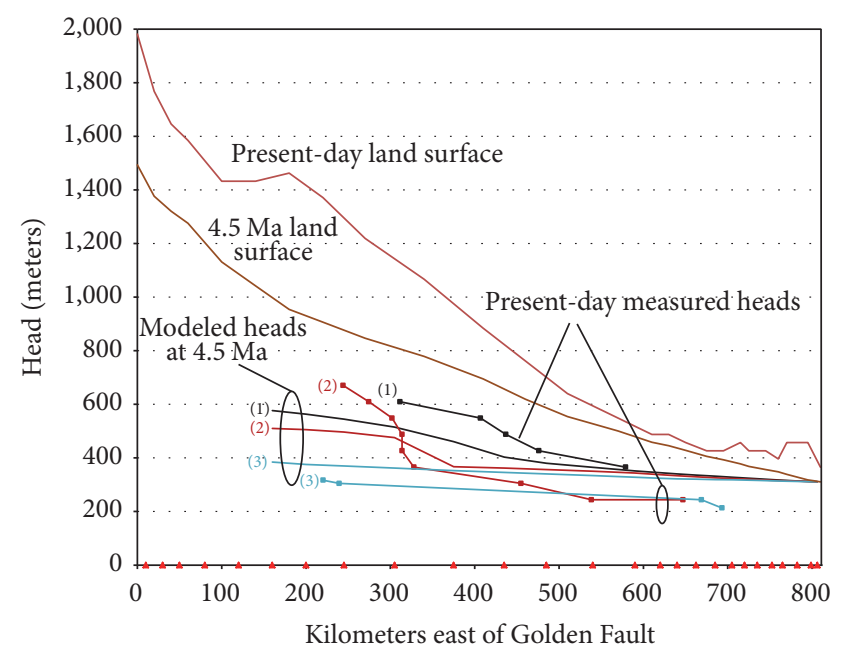

(1) Wolfcampian

(2) Desmoinisian

(3) Mississippian

Figure 30: Results of running the fifth model, the $4.5 \mathrm{Ma}$ model, representing the 2.5-million-year period from 7 to $4.5 \mathrm{Ma}$, compared to present-day heads. Model curves (1), (2), and (3) (Wolfcampian, Desmoinesian, and Mississippian, resp.) are further approaching the present-day data curves. Red triangles at centroids of the grid columns mark the initial zero heads at $70 \mathrm{Ma}$.

if $K$ in the Ogallala, Laramide Basin Fill, and Dakota were to be increased by 2 orders of magnitude, the conceptual model of isolation of the deeper units would be compromised, $h$ in the Wolfcampian would change by -8.95 percent (Table 7 ), and the heads in the deeper aquifers would not be matched as well.

Results of the sensitivity analysis given above are summarized in Table 7.

3.3.7. Model Limitations. As stated under Creating and Calibrating the Hydrologic Model to Simulate Structurally Driven Underpressures, even though we refer to values of $S_{s}$ and $K$ $\left(K_{h}\right.$ and $\left.K_{v}\right)$ obtained by the sequence of models as "optimal," it should be noted that the sequence of models and their solution presented here is not unique, and other combinations of flux, $S_{s}$, and $K$ values could have produced calculated present-day hydraulic head values as close, or closer, to the actual present-day hydraulic head values.

The model geometry is rather simple, or coarse, with only 26 columns in the $x$ direction covering a horizontal distance of $800 \mathrm{~km}$ and 10 layers in the $z$ direction covering a vertical distance of $4 \mathrm{~km}$, and aquifer properties $\left(K\right.$ and $S_{s}$ ) are assumed to be homogenous in each model cell. Likewise, the one-million year time steps of the diffusive hydrologic model could be shortened as the uplift history becomes more refined. Shorter time steps and keeping the diffusive and uplift (model) time steps the same would result in better estimates of equilibration times. 
TABLE 7: Sensitivity analysis (OM: order of magnitude, Og: Ogallala, Lbf: Laramide Basin Fill, Dak: Dakota, Wolfc: Wolfcampian, Virg: Virgilian).

\begin{tabular}{|c|c|c|c|c|c|c|}
\hline & $\begin{array}{c}K_{h} \text { in } \mathrm{m} / \mathrm{d}\left(K_{v}=0.1\right. \\
\left.K_{h}\right)\end{array}$ & $Q$ in $\mathrm{m}^{3} / 1,000 \mathrm{yr}$ & $S_{s}$ & $\begin{array}{l}h \text { in Wolfcampian } \\
\text { at } 200 \mathrm{~km} \text {, in m }\end{array}$ & $\begin{array}{c}h \text { in Wolfcampian } \\
\text { at } 200 \mathrm{~km}, \% \\
\text { change }\end{array}$ & See figure \\
\hline Base case & & 474.5 & $1 \times 10^{-6}$ & 119.90 & 0 & \\
\hline Og, Lbf, Dak & $1 \times 10^{-6}$ & & & & & \\
\hline Wolfc, Virg, & $5 \times 10^{-4}$ & & & & & \\
\hline Desmoinesian, & $5 \times 10^{-3}$ & & & & & \\
\hline Mississippian & $5 \times 10^{-3}$ & & & & & \\
\hline $\begin{array}{l}1 / 2 \text { OM increase in } \\
K \text { of aquifers: }\end{array}$ & & & & 89.21 & -25.6 & Figure 23 \\
\hline Wolfc, Virg, & $1 \times 10^{-3}$ & & & & & \\
\hline Desmoinesian, & $1 \times 10^{-2}$ & & & & & \\
\hline Mississippian & $1 \times 10^{-2}$ & & & & & \\
\hline $\begin{array}{l}1 / 2 \text { OM decrease } \\
\text { in } K \text { of aquifers: }\end{array}$ & & & & 200.03 & +66.83 & Figure 24 \\
\hline Wolfc, Virg, & $1 \times 10^{-4}$ & & & & & \\
\hline Desmoinesian, & $1 \times 10^{-3}$ & & & & & \\
\hline Mississippian & $1 \times 10^{-3}$ & & & & & \\
\hline $\begin{array}{l}2 \text { OM higher } K \text { in } \\
\text { Og, Lbf, Dak }\end{array}$ & $1 \times 10^{-4}$ & & & 109.167 & -8.95 & Figure 27 \\
\hline Double $Q$ in west & & 949.0 & & 152.05 & +26.81 & Figure 21 \\
\hline Halve $Q$ in west & & 237.3 & & 96.73 & -19.33 & Figure 22 \\
\hline $1 \mathrm{OM}$ higher $S_{s}$ & & & $1 \times 10^{-5}$ & 200.67 & +67.36 & Figure 25 \\
\hline $1 \mathrm{OM}$ lower $S_{s}$ & & & $1 \times 10^{-7}$ & 74.96 & -37.48 & Figure 26 \\
\hline
\end{tabular}



(1) Wolfcampian
(2) Desmoinisian
(3) Mississippian

FIGURE 31: Results from the $0 \mathrm{Ma}$ model, representing the 2million-year period from 2 to $0 \mathrm{Ma}$ and present-day head values. Model curves (1), (2), and (3) (Wolfcampian, Desmoinesian, and Mississippian, resp.) approximate the present-day data curves. Red triangles at centroids of the grid columns mark the initial zero heads at $70 \mathrm{Ma}$.

The 2-dimensional vertical nature of the models assumes only flow in the horizontal $x$ (length) and vertical $z$ (depth) directions and that no flow takes place in the horizontal $y$ direction.

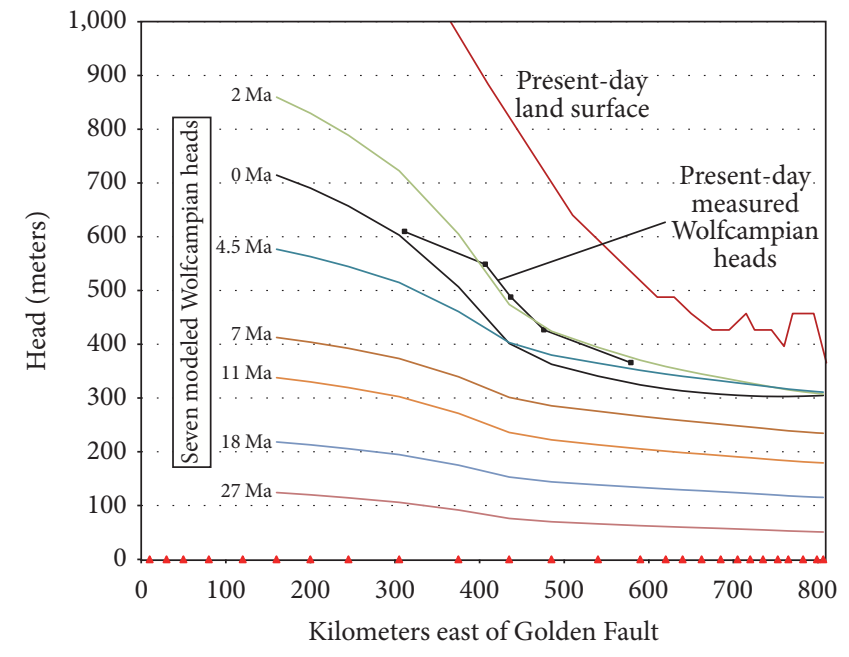

FIgURE 32: Progression of Wolfcampian head solutions from 27 to $0 \mathrm{Ma}$.

\section{Results and Discussion}

We have selected four of the nine models to show the buildup of land surface and hydraulic head with time: the 27, 18, 4.5, and $0 \mathrm{Ma}$ models, which sample the periods of nondeposition, deposition of the Ogallala, and erosion (Figure 8). Figures 28-31 display the land surface and hydraulic head at the end of each time period, as well as the present-day land surface and hydraulic head profiles. The sequence of models utilizes the optimal values of flux from the west and hydraulic conductivity values, as previously discussed. The four figures 


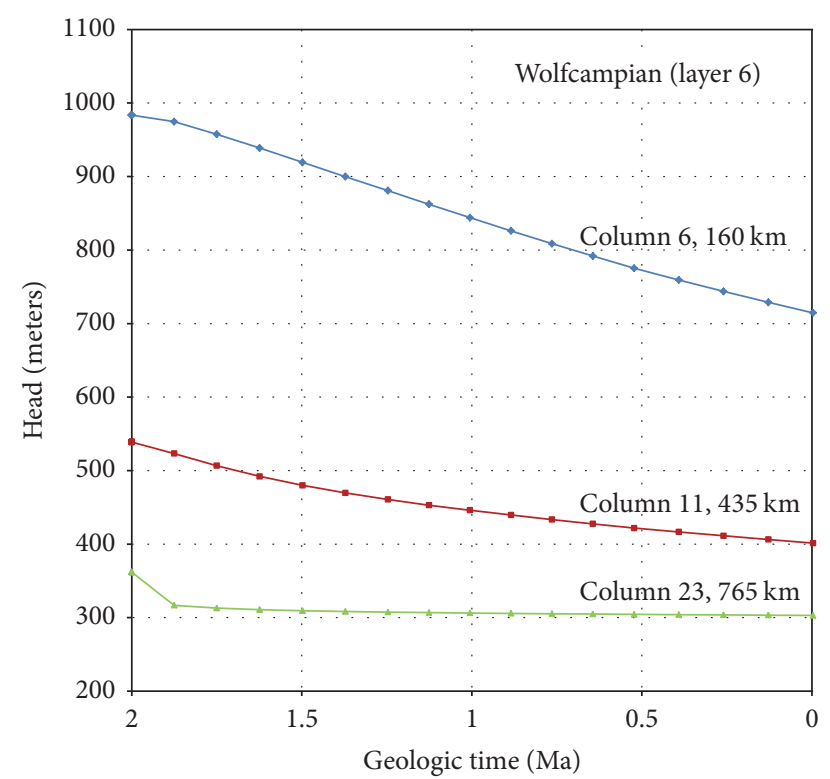

FIgURE 33: Head versus time for Wolfcampian cells in columns 6, 11, and 23 of the $0 \mathrm{Ma}$ model, representing the period from 2 to $0 \mathrm{Ma}$. At $0 \mathrm{Ma}$, the solution has equilibrated at the eastern part of the crosssection but has not reached steady state in the central and western parts of the model.

show the progression from zero head values at $40 \mathrm{Ma}$ to the near-match of underpressured head values at $0 \mathrm{Ma}$ for the Wolfcampian, Desmoinesian, and Mississippian hydrologic units.

At $27 \mathrm{Ma}$, head values for the three hydrologic units are approximately $100 \mathrm{~m}$ at $x=160 \mathrm{~km}$, less than the land surface elevation of $200 \mathrm{~m}$ (Figure 28). Thus, heads at $27 \mathrm{Ma}$ are roughly half of land surface along most of the crosssection, showing the early development of underpressure. The eastern boundary condition ( $h=$ surface elevation) prevents the development of any underpressure at $x=$ $800 \mathrm{~km}$. At $18 \mathrm{Ma}$ (Figure 29), the amount of underpressure, equivalent to the separation between land surface and head, increases in the west and separation among the three modeled heads-Wolfcampian, Desmoinesian, and Mississippian-is more visible. These four trends-(1) higher land surface elevation; (2) increasing head; (3) increasing underpressure in the west; and (4) increasing differentiation among the three hydrologic units-are progressively more manifest at the end of 4.5 Ma (Figure 30) and 0.0 Ma (Figure 31). In addition, we observe a concavity developing in the modeled Wolfcampian and Desmoinesian hydraulic head curves at $24 \mathrm{Ma}$, similar to what is seen in the present-day data. At $0 \mathrm{Ma}$ (Figure 31), the modeled hydraulic head values of the Wolfcampian, Desmoinesian, and Mississippian units approximate their corresponding present-day hydraulic head values.

Figure 32 presents the progression of seven of the nine modeled Wolfcampian hydraulic head values for the $27 \mathrm{Ma}$ through $0 \mathrm{Ma}$ models (for visible clarity, the 3.5 and $3 \mathrm{Ma}$ models are not shown). Figure 32 shows that, through the series of nine models, the Wolfcampian modeled head values gradually approach, and eventually approximate, the presentday Wolfcampian measured hydraulic head values, also shown in Figure 31. Note that the hydraulic head values for the $2 \mathrm{Ma}$ model are larger than the $0 \mathrm{Ma}$ values. The decrease in the hydraulic head values from 2 to $0 \mathrm{Ma}$ is the result of fixing the hydraulic head values on the eastern boundary to the geohydrologic unit elevations, as described under Boundary Conditions (BCs) for the Sequence of Models.

Figure 33 presents the modeled hydraulic head values with time for 3 model columns $(6,11$, and 23 ; located at 140 , 410 , and $740 \mathrm{~km}$ ) of the Wolfcampian layer for the period from 2 to $0 \mathrm{Ma}$. Figure 33 shows that the hydraulic head values at $0 \mathrm{Ma}$ have not reached steady state. This is especially clear when compared to Figure 20, where steady state does occur during the modeled period at all locations. This result is significant because it indicates that present-day hydraulic heads are not at equilibrium and that, consequently, underpressures are going to increase in the future (beyond $0 \mathrm{Ma}$ ). The pattern uncovered by the series of 9 MODFLOW models is of increased underpressures with each subsequent model, as discussed earlier when comparing the underpressures in Figures 28, 29, 30, and 31. Overall, the models indicate that the tectonic uplift plays a primary role in the development of underpressures in the Great Plains.

\section{Summary and Conclusions}

From the geologic evidence, we have constructed an uplift history for the Great Plains plotted as cumulative uplift as a function of time from $27 \mathrm{Ma}$ to the present, with superimposed periods of deposition and erosion.

The uplift history is embedded in 9 two-dimensional cross-sectional models, based on a geologic cross-section running from northeast Colorado to southeast Kansas. Tectonic uplift, deposition, and erosion were incorporated as changes in the surface elevation, geohydrologic unit elevation, and hydraulic heads at the beginning of each MODFLOW run. Fluxes were specified on the western boundary and constant heads were specified on the eastern boundary. The hydraulic heads at the beginning of each MODFLOW run (the initial heads) were assumed to be the values from the previous model run plus the increase in elevation due to tectonic uplift. This process was repeated until the calculated heads of the $0 \mathrm{Ma}$ model, that is, the calculated presentday heads, were obtained. Hydraulic conductivity values and western specified-flux values were varied until the presentday calculated heads were as close as possible to known (measured) present-day heads.

The results from the sequence of MODFLOW models indicate a gradual increase in hydraulic heads and development of underpressures. Early models, such as the first model (40 to $27 \mathrm{Ma}$ ), indicate that the modeled Wolfcampian, Desmoinesian, and Mississippian heads are substantially different from the corresponding present-day Wolfcampian, Desmoinesian, and Mississippian hydraulic head data. Later models, such as the 7 to $4.5 \mathrm{Ma}$ model, indicate that the modeled hydraulic head values of the Wolfcampian, Desmoinesian, and Mississippian units continue to rise, though not 
as rapidly as the land surface. Consequently, comparison of the modeled hydraulic head values to the $4.5 \mathrm{Ma}$ land surface shows a continued increase in the underpressures and also indicates development of a downward concavity of the Wolfcampian and Desmoinesian hydraulic heads in the west, similar to what is seen in the present-day data. The final model ( 2 to $0 \mathrm{Ma}$ ) indicates that the modeled hydraulic head values of the Wolfcampian, Desmoinesian, and Mississippian units approximate their corresponding present-day hydraulic head values. The model also provides a good representation of the present-day underpressures measured in the Wolfcampian, Desmoinesian, and Mississippian units. The modeled and measured hydraulic head values also indicate that the underpressures increase to the west.

The 2 to $0 \mathrm{Ma}$ model indicates that the present-day hydraulic head value of the Wolfcampian geohydrologic unit has not reached steady state. This result is significant because it indicates that present-day hydraulic heads are not at equilibrium and, therefore, underpressures are going to increase in the future. The pattern uncovered by the series of 9 MODFLOW models is of increased underpressures with time. Overall, the models indicate that tectonic uplift explains the development of underpressures in the Great Plains.

\section{Appendix}

\section{A. Theoretical Basis of Underpressure}

To understand what underpressure means, the following definition of hydraulic head is needed. Hydraulic head $(h)$, in units of $\mathrm{L}$, is given by

$$
h=\frac{p}{\gamma}+z
$$

where $p$ is the hydraulic pressure at a location $\left[\mathrm{F} \mathrm{L}^{-2}\right], \gamma$ is the unit weight of water $\left[\mathrm{F} \mathrm{L}^{-3}\right]$, and $z$ is the elevation ("elevation head") above a datum [L] (L represents units of length and $\mathrm{F}$ units of force). In (A.1), $p / \gamma$ has units of $L$ and is the "pressure head," representing the height of a column of water that produces the pressure $p$ at its bottom for normal hydrostatic pressure conditions. Equation (A.1), therefore, says that the hydraulic head equals pressure head plus elevation head.

For a hydrostatic system, where the pressure head at a point is equal to the depth of submergence of the point, the hydraulic head is constant throughout, including at the water table. Alternately, at any point in an aquifer, if the fluid pressure is equal to normal hydrostatic pressure (i.e., pressure head is equal to the depth of submergence), the hydraulic head at that point is equal to the hydraulic head at the water table.

Underpressure, on the other hand, is the condition where pore fluid pressure (hydraulic pressure) is below normal hydrostatic pressure for a point in the aquifer (the pressure: depth ratio is less than that of a hydrostatic column; [7]). Hence, it follows that, for a depth where fluid pressure is below normal hydrostatic pressure, the hydraulic head is less than the hydraulic head at the water table, as depicted in Figure 1. Note that, in Figure $1, p / \gamma$ is the pressure head at the observation point relative to the potentiometric surface, not the water table.

Thus, the following definition can be made: underpressure is the condition where the hydraulic head is less than the hydraulic head at the water table. The amount that the hydraulic head at a point is less than the hydraulic head at the water table is the amount of underpressure, represented by the term Up_real in Figure 1.

Additionally, if the vertical distance between the water table elevation (WT) and land surface elevation (GL), namely, GL-WT, as shown in Figure 1, is negligible relative to GL like in the case of deep aquifers with shallow water tables, then the hydraulic head at the water table is approximately equal to the land surface elevation. In these cases, which are assumed in this report, the above definition of underpressure can be restated as follows: underpressure is the condition where the hydraulic head is less than land surface elevation. The amount by which $h$ is less than GL is the approximate amount of underpressure, depicted as Up_approx in Figure 1. The data and model results in this paper are presented with reference to hydraulic head $(h)$ and land surface elevation (GL), from which Up_approx can be calculated as GL $-h$.

\section{B. Expanded Geologic Setting}

The central Great Plains are a vast, almost monotonically eastward-sloping terrain that stretches from the front of the southern Rocky Mountains eastward to the Mississippi River at the meandering eastern and northeastern boundaries of Nebraska and Kansas, respectively (Figure 2). Elevations range from about 200 meters above sea level in the east to almost 2000 meters locally at the western limit of the Great Plains. Slopes within this tilted terrain are dominantly low (gentle) but become progressively steeper to the west. The resulting form is very gently concave upward relative to the steep but nonvertical axis of this very long wavelength and very low amplitude tilted synclinal fold (Figure 7). No closed low is present in the center of this noncontractional fold because the tilting greatly exceeds the folding; thus, it is not a true syncline.

Eaton [11, 12] interpreted the Great Plains as the eastern flank of a huge antiformal uplift (Figures 3 and 4) that is centered on the Rio Grande rift and includes the Colorado Plateau as its western flank. The Rio Grande rift (Figures 4 and 5) in turn is partly coincident with the southern Rocky Mountains (Figure 4), and the current high elevation of this mountain range dates only to uplift of this antiformal bulge, which entirely postdates the original formation of these mountains in the Laramide ( $\sim 70$ to $\sim 40 \mathrm{Ma})$ orogeny. Eaton [11] called this giant domal uplift the Alvarado ridge, a name that has not caught on but which nevertheless represents an important observation. Timing constraints indicate that uplif t of the Alvarado ridge followed a similar history throughout its geographic range $[11,12]$, indicating it is a unitary tectonic (epeirogenic) landform-despite the overwhelming focus in the literature on the uplift of the Colorado Plateau and the resulting incision of the Grand Canyon. 
Rocks exposed across the central Great Plains include the upper Cenozoic ( 18 to $\sim 4.5 \mathrm{Ma}$ ) Ogallala alluvial conglomerate, Laramide fills of foreland basins (such as the Denver Basin, Figure 2), Upper Cretaceous marine shales and shoreline sandstones, and, in eastern Kansas, Paleozoic marine limestones and related rocks (Figure 6). Studies of the Ogallala Formation indicate that it has been strongly tilted in the western Great Plains and only weakly tilted in the eastern plains $[18,19]$, indicating that it is folded in a fashion that mimics the overall geomorphology of the Great Plains.

Moreover, several major subsurface structures (basins and anticlines) are present at depth under the Great Plains (Figure 2), and none of these have anything but erosional geomorphic expression, including the Laramide basins, indicating that the uplift of the plains is entirely late Cenozoic (after $40 \mathrm{Ma}$ ). The lack of geomorphic expression of the buried structures under the Great Plains is particularly clear in cross-section (such as in Figure 7). Further, the generally steep front of the southern Rocky Mountains is entirely an erosional landform in its current expression. The history of uplift of the Great Plains is recorded in its tectonostratigraphy.

\section{B.1. Tectonostratigraphy and Hydrostratigraphy}

B.1.1. Early Paleozoic. Cambrian through Mississippian rocks under the central Great Plains are marine limestones and dolomites and lesser interbedded shales deposited when shallow seas covered nearly all of the midcontinental United States. An interval of uplift and erosion at the end of the Mississippian resulted in removal of the lower Paleozoic rocks from east-central Colorado westward to the front of the southern Rocky Mountains and beyond. Over the remainder of the study area, where these rocks are still present, the early Paleozoic rocks have nearly ubiquitous development of a karstic weathering profile at the top.

This karstic horizon is the most transmissive aquifer/ reservoir rock under much of the central Great Plains. Moreover, the whole early Paleozoic section appears to act as a single continuous geohydrologic unit as indicated by potentiometric continuity [7]. The uninterrupted nature of the karstic profile results in excellent continuity of this unit over much of the study area. None of the interbedded shales appears to act as a significant confining unit, at least on a regional basis. Because of the westward pinch-out under the Plains, the lower Paleozoic rocks receive no recharge from the west. Further, these strata are capped by a basal Pennsylvanian section which is a confining unit, strongly restricting recharge from overlying strata.

B.1.2. Late Paleozoic. Pennsylvanian and Permian strata under the central Great Plains are mainly marine rocks in the east changing westward to almost exclusively terrestrial rocks in the far west at the front of the southern Rocky Mountains and for at least tens of kilometers to the east of that front. Under at least half of the central Great Plains, the Pennsylvanian-Permian rocks exhibit a complex intertonguing of marine and terrestrial rocks. The purely terrestrial rocks are clastic sediments derived from PennsylvanianPermian uplifts that formed at the time, mainly in central and western Colorado, which are known as the Ancestral Rocky Mountains. Because of the abundant clastic-sediment supply that existed, a majority of the upper Paleozoic marine rocks are also clastic sediments, although they contain usually thin, but very widespread, carbonate beds. Extensive and locally thick evaporite deposits are present at the marine/terrestrial contact in many parts of the study area, reflecting episodic marine incursions.

The Pennsylvanian-Permian interval was one characterized by numerous marine transgressions and regressions, reflecting repetitive episodic sea-level fluctuations related mainly to glaciations but also to tectonic events in some cases. Because of the very low relief of much of the midcontinent in this interval, the marine shoreline moved hundreds of kilometers westward and then back eastward in these transgressions and regressions, respectively. Consequently, the marine carbonate horizons are aquifers/reservoir rocks with regional-scale physical and hydrologic continuity in many cases, much like the karstic lower Paleozoic hydrologic unit.

Unlike the lower Paleozoic rocks, however, the upper Paleozoic sections contain a number of confining units, mainly shales. On a regional basis, two of these confining units are important. One of these separates the Wolfcampian, Virgilian, and Missourian aquifers from the lower part of the Pennsylvanian, as indicated by differing pressure regimes [7]. The second, part of the Upper Permian section, consists almost entirely of shale and evaporites and is a confining unit restricting recharge to the upper Paleozoic strata from above. Further, recharge from the west is restricted by the westward facies change to exclusively terrestrial rocks, both because the latter are low-permeability rocks in general and because the permeable beds within the section lack continuity across the marine/terrestrial transition.

Many of the arches and basins that are buried under the central Great Plains, such as the Las Animas arch (Figure 2), were active during the late Paleozoic. Consequently, the upper Paleozoic section, and especially the carbonate beds in this section, thin over this arch and other related features. This thinning over buried uplifts is accompanied by an increase in the clastic content of carbonate beds in the section, resulting in lower permeability in these areas.

B.1.3. Early and Middle Mesozoic. The Triassic, Jurassic, and Lower Cretaceous section in the midcontinent is very thin in general and is discontinuous in many areas. This section consists of terrestrial sediments which are generally low in permeability. Hydraulically, this section is continuous with the Upper Permian shale and evaporite section and acts as part of this confining unit.

B.1.4. Late Cretaceous. The vast majority of Upper Cretaceous strata under the Great Plains are black shales, which were deposited in the Cretaceous Western Interior Seaway. These shallow-water pelagic deposits (mainly the Pierre and Niobrara Shales, Figure 7) are underlain and capped by horizons which record a major transgression and a major regression near the beginning and end of the Late Cretaceous, respectively. These events resulted in deposition of widespread marine shoreline sandstones over the area of 
the Great Plains-the Dakota and Trinidad Sandstones and their stratigraphic equivalents [20]. These marine shoreline deposits as well as the shallow-water nature of the thick intervening black shales prove that, for tens of millions of years prior to the onset of the $\sim 70$ - to $\sim 40$-Ma Laramide orogeny, the area of the Great Plains was close to sea level.

The Upper Cretaceous black shale is very thick over all but the eastern quarter of the study area (Figure 7). This shale is the most effective confining unit in the study area, strongly restricting recharge to all of the aquifers/reservoir rocks that underlie it. The Dakota Sandstone is an aquifer that is much thinner and less permeable than the underlying Paleozoic aquifers/reservoir rocks. The extreme vertical exaggeration of the cross-section (Figure 7) precludes showing that this unit is bent up to the surface immediately east of the front of the Rocky Mountains, where it crops out in a narrow hogback. The Dakota Sandstone receives minor recharge from this small-footprint exposure but receives no recharge from the mountains to the west because it does not quite extend to the mountains.

B.1.5. The Laramide Orogeny. Laramide strata of the Great Plains are the fills of foreland basins, such as the Denver Basin, which formed in the $\sim 70$ to $\sim 40 \mathrm{Ma}$ Laramide orogeny-during the contractional uplift of the Rocky Mountains and the local formation of the Golden Fault at the mountain front (not shown in Figure 7, but western end of geologic cross-section $\mathrm{A}-\mathrm{A}^{\prime}$ is at the mountain front). Numerous workers have observed the predominantly finegrained nature and thus low-energy depositional environment of these terrestrial basin fills. This is consistent with other evidence (e.g., [21]) indicating that these foreland basins, and thus the area of the future Great Plains itself, remained near sea level during the initial contractional uplift of the adjacent Rocky Mountains. The Laramide strata are present only in the westernmost part of the study area (Figure 7) and contain no major aquifers. Where present, this section adds extra confinement to the deep aquifers/reservoir rocks under the Plains, beyond that provided by the Pierre and Niobrara Shales.

B.1.6. Post-Laramide Time. From shortly after the end of the Laramide orogeny (at $\sim 40 \mathrm{Ma}$ ) to just before the beginning of formation of the Rio Grande rift (at $27 \mathrm{Ma}$ ), subduction continued along the west coast of North America; however, contractional uplift of the southern Rocky Mountains had ceased. This was an interval of widespread subduction-related volcanism in and around the southern Rocky Mountains [22]. Eaton [11] has inferred that uplift of the Alvarado ridge began during the interval of $\leq 40$ to $\sim 27 \mathrm{Ma}$; however, he provides no evidence to support that interpretation. In the few cases where data exist that can be directed at testing this minor element of Eaton's [11] interpretation, no support was found for onset of uplift of the Alvarado ridge, including the variable uplift/tilting of the Great Plains, before initiation of Rio Grande rifting at $\sim 27 \mathrm{Ma}$.

Late Eocene/early Oligocene sediments ( 34 Ma) in the area of Florissant, Colorado, are currently at $\sim 2500 \mathrm{~m}$ elevation but were only $\sim 300 \mathrm{~m}$ above sea level at the time of deposition, based on an analysis of plant fossils [23]. This fossil evidence is somewhat controversial but provides supportive evidence that major uplift of the Alvarado ridge did not occur until after the interval of subduction-related volcanism during $\leq 40$ to $\sim 27 \mathrm{Ma}$. Lava vesicle paleoaltimetry from flows of different ages on different parts of the Alvarado ridge [24] provides more definitive evidence and is consistent with the above conclusion.

The onset of (Rio Grande) rifting to the southwest of the study area (near the central Colorado/New Mexico border) at $\sim 27 \mathrm{Ma}$ was accompanied by an early stage of uplift and of resulting erosion [13]. Erosion in the highest part of the Great Plains in the southern part of the study area-across most of northeastern New Mexico and in a small part of adjacent southeastern Colorado-extended to $\sim 18 \mathrm{Ma}$, when deposition of the Ogallala Formation began. In contrast, in at least the early part of the same interval, the more northerly Great Plains, in the vicinity of the Colorado/Wyoming border, remained a depocenter, mainly for fine-grained deposits of the Eocene to Oligocene White River and late Oligocene to early Miocene Arikaree Formations, which were evidently deposited in a swampy environment [13]. The formation of the Rio Grande rift itself was diachronous, with onset starting in southern New Mexico at $30 \mathrm{Ma}$ and progressing northward to the area of the Colorado/Wyoming border at $\sim 25 \mathrm{Ma}$ (R. A. Thompson, USGS, oral comm., 2015).

Erosion/deposition patterns on the Great Plains indicate that uplift/tilting of the eastern flank of the Alvarado ridge followed a northward-migrating diachronous pattern that was similar to that of the onset of rifting. Whereas onset of uplift of the Great Plains was slightly staggered behind that of the Rio Grande rift, the time of maximal uplift of all parts of the Alvarado ridge were strongly staggered behind the predominant time of formation of the rift. For example, the tectonostratigraphy of the Great Plains indicate that approximately half of the uplift and tilting occurred from latest Miocene time $(\sim 6 \mathrm{Ma})$ to the present, as discussed below. Whereas a small number of data points, mainly from the Grand Canyon, have been interpreted as indicating a much earlier uplift of the western part of the Alvarado ridge (at 70 Ma; [25]), most workers find this conjectural interpretation to be irreconcilable with the majority of available data, most of which are more reliable and robust than the questionable uplift data from the Grand Canyon (e.g., see [26]).

The roughly east-west cross-section that we have constructed as part of our framework model (Figure 7) lies approximately halfway between the Colorado/New Mexico and Colorado/Wyoming border areas in which the $\sim 27$ to $\sim 18 \mathrm{Ma}$ interval was one of erosion and one of deposition, respectively. On the line of section itself, which was chosen to be along the section line published in Nelson et al. [7], there is no evidence as to whether erosion or deposition was occurring in this interval, and thus we have assumed nondeposition in this interval along the line of section as the simplest assumption from available evidence.

The interval from $\sim 18$ to $\sim 4.5 \mathrm{Ma}$ on the Great Plains was characterized by deposition of a vast alluvial apron covering most or all of the Plains. These alluvial deposits are known 
as the Ogallala Formation, which is an important water-table aquifer in a major part of the Plains. The early stages of uplift of the Alvarado ridge precipitated formation of this alluvial apron [14]. Continued uplift and tilting eventually created grades steep enough to end deposition of this apron and to initiate erosion. Strong tilting of the Ogallala in the western part of the Great Plains indicates that at least about half of the uplift and tilting followed the transition from deposition to erosion.

The major area of preservation of the Ogallala alluvial apron is in the central part of the Great Plains. The base of the formation in this central area is a concave-upward surface that is almost certainly a tectonic fold (see Figure 7). As discussed above, the Great Plains are not simply tilted eastward, but they have also been bent into a concaveupward surface during epeirogeny as a result of the nonlinear nature of the uplift. Additionally, the major mass of preserved Ogallala Formation probably has escaped erosion at least partly because it is relatively protected from erosion within the central part of the tectonic concavity. Near the Colorado/Wyoming border, the Ogallala Formation is locally preserved in the far western part of the Great Plains in a feature known as the "gangplank." Tiny remnants of the Ogallala Formation are also found capping small knolls in eastern Kansas [27]. Thus, it appears that the Ogallala Formation was deposited over virtually the entirety of the Great Plains during an early stage of uplift of the Alvarado ridge, based on evidence from McMillan et al. [28].

The vast majority of the erosion after $27 \mathrm{Ma}$ on the Great Plains evidently occurred from $\sim 4.5 \mathrm{Ma}$ to the present-after deposition of the Ogallala Formation ceased. A number of different, mainly Quaternary, formations were deposited locally on the Great Plains during this interval, mainly as the caps of terraces formed during downcutting. Erosion rates can be estimated from the relative heights of these differentage deposits to yield estimates of the change in erosion rate during the interval of $\sim 4.5 \mathrm{Ma}$ to the present. However, the rates so obtained are all within the error bars of estimation (E. Taylor, USGS, oral comm., Denver), and thus the simplest assumption that satisfies existing data is a constant erosion rate since $\sim 4.5 \mathrm{Ma}$.

Current slopes across the Great Plains average $\sim 10^{-3}$ and, in at least the steeper western half of these plains, are well in excess of the $10^{-4}$ to $10^{-3}$ slopes [28] estimated during the time of deposition of the Ogallala Formation. This and the sustained pattern of downcutting throughout the Great Plains since $\sim 4.5 \mathrm{Ma}$ reflect a much stronger pattern of uplift since $\sim 4.5 \mathrm{Ma}$ than in the preceding $\sim 27$ to $\sim 4.5 \mathrm{Ma}$. Whereas it is difficult if not impossible to quantify this, it appears likely that at least about half of the total uplift of the Great Plains occurred in the interval of $\sim 4.5 \mathrm{Ma}$ to the present, which is the same approximate timing that has been estimated for the western half of the Alvarado ridge (the Colorado Plateau; [26]) and within the area of the Rocky Mountains [29, 30].

Paleoelevation estimates based on basalt vesicle studies [24] indicate that about 50 percent of total uplift of the Alvarado ridge occurred from $\sim 27$ to $\sim 5 \mathrm{Ma}$ and the remaining half from $\sim 5 \mathrm{Ma}$ to the present. Further, studies in the vicinity of the "gangplank" show that late Pliocene sediments are not discernibly tilted, although only strong tilting is discernible. Thus, we have concluded that uplift peaked in the Pliocene and has been lesser in the Quaternary.

\section{Permeability and Hydraulic Conductivity Values from Other Sources}

In this appendix, values of permeability (and equivalent hydraulic conductivity values) chosen for two previous hydrologic modeling studies of the Great Plains are summarized. These values can be compared with values chosen for the model.

The underpressured deep brine aquifers of the Palo Duro Basin in the Texas Panhandle were studied with a twodimensional model to understand the causes of underpressuring and the nature of deep groundwater circulation [31]. Figure 19 shows the permeability values used in their model for Triassic, Permian, and Pennsylvanian strata. The most important rock unit of the deep basin brine aquifer, the Permian-Pennsylvanian shelf carbonate facies, was assigned a value of $0.013 \mathrm{~m} \mathrm{~d}^{-1}$ based on values for Wolfcampian carbonates, Pennsylvanian carbonates, and pre-Pennsylvanian strata. The ratio of vertical to horizontal permeability $k_{v} / k_{h}$ was set to 0.01 for the shelf carbonate facies. Other values of $k_{v} / k_{h}$ range from 0.01 in a salt dissolution zone to 0.1 in a fluvial-lacustrine system to 1.0 in low-permeability salt and basinal systems.

In considering the selection of permeability values for a regional study of the Great Plains, Signor et al. [16] produced a series of maps of $k_{h}$ for each of their aquifer systems. Values of $k_{h}$ were computed from porosity values obtained from geophysical logs. Values from their maps, taken along the cross-section shown in Figure 7, are summarized in Figure 18. The lower units of the Western Interior Plains Aquifer System of Signor et al. corresponds to rock units of Ordovician and Silurian age, while the upper units correspond to rock units of Mississippian age. In the present paper, both the lower and upper units of the Western Interior Plains Aquifer System are combined into the Mississippian and Cambrian-OrdovicianSilurian hydrologic unit. The third grouping of Figure 18, the Western Interior Plains Confining System, comprises rock units ranging from Pennsylvanian to Jurassic in age, which are treated in the present paper as five distinct hydrologic units: Basal Pennsylvanian, Desmoinesian, MissourianVirgilian, Wolfcampian, and Upper Permian-Jurassic. The Lower Cretaceous is named the Dakota hydrologic unit in this paper, but it was not modeled.

\section{Definitions of Terms}

\{\}$:$

$\{0\}:$

$\gamma:$

Actual present-day hydraulic head values:
Vector (list) of values

Vector of zeros

Gamma; unit weight of water $\left[\mathrm{FL}^{-3}\right]$

Actual present-day hydraulic head data values observed in the field or derived from field observations 


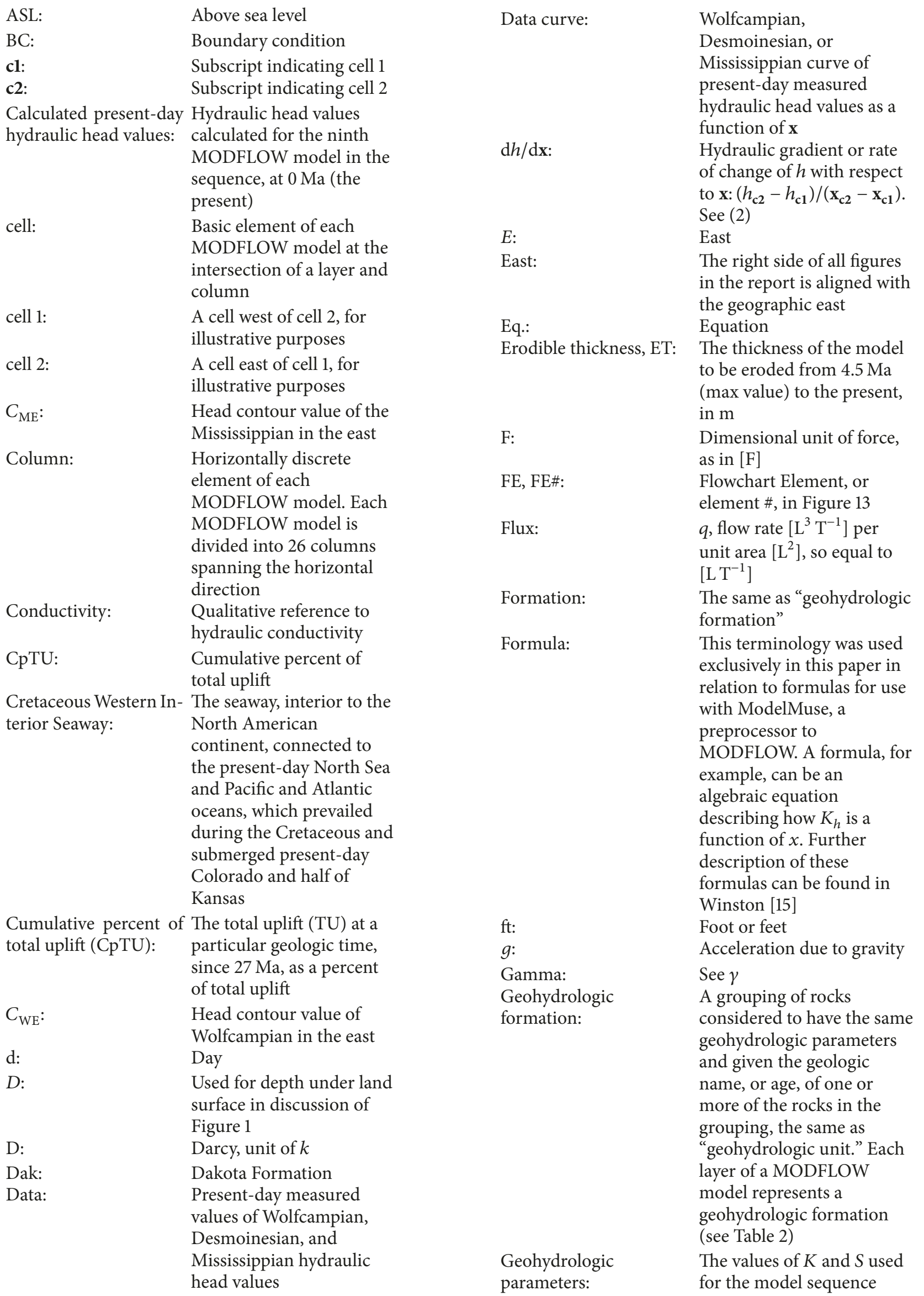


Geohydrologic unit:

Geometry:

Great Plains:

Grid:

$h:$

$h:$

$h_{\mathrm{cl}}$ :

$h_{\mathrm{c} 2}$ :

$h_{E}$ :

$h_{i}$ [distinct from $\left\{h_{i}\right\}$ ]:

$\left\{h_{i}\right\}:$

$\{h\}:$

$\{h\}_{18 \mathrm{Ma}}$ :

$\{h\}_{27 \mathrm{Ma}}$ :

Head:

Head plot:

Hydraulic gradient: Hydraulic head:

Hydraulic head plot:

$i:$

$K$ :
The same as "geohydrologic $\quad k$ formation"

The geometry of a model is the layout of columns and

layers of a model; see

"MODFLOW model"

Physiographic region of

North America, bordered by

the Southern, Middle, and

Northern Rocky Mountain

physiographic regions to the west and the Central

Lowland physiographic

region to the east

The grid of a model, the

same as "geometry"

Hydraulic head, [L], m

The subscript ${ }_{h}$, as in $K_{h}$, or

$q_{h}$, indicates the horizontal

direction

Hydraulic head, $h$, at cell 1

Hydraulic head, $h$, at cell 2

Head specified in $E$ (east)

Temporally interpolated

head between $h$ at $4.5 \mathrm{Ma}$, calculated by the $4.5 \mathrm{Ma}$

model, and $C_{\mathrm{WE}}$ at $0 \mathrm{Ma}$ for

layers (1) through (7), and

between $h$ at $4.5 \mathrm{Ma}$ and $C_{\mathrm{ME}}$

at $0 \mathrm{Ma}$ for layers (8) through

(10). This $h_{i}$ is used as $h_{E}$ for

the $3.5,3,2$, and 0 Ma models

Initial $\{h\}$ for a model run,

distinct from $h_{i}$

Vector, or list, of hydraulic

heads for all the cells in a

model

$\{h\}$ at $18 \mathrm{Ma}$

$\{h\}$ at $27 \mathrm{Ma}$

The same as

"hydraulic head"

Plot of head, $h$, versus $\mathbf{x}$, the same as "hydraulic head

plot"

See $\mathrm{d} h / \mathrm{d} \mathbf{x}$

$h$; summation of "elevation

head" and "pressure head," $z$ and $p / \gamma$ in (A.1)

A plot of hydraulic head, $h$, versus $\mathbf{x}$

Subscript indicating "initial” in $\left\{h_{i}\right\}$ and "temporally interpolated" in $h_{i}$

Hydraulic conductivity

(depends on medium, $k$, and

fluid properties): includes $K_{h}$ and $K_{v}$. $\left[\mathrm{L} \mathrm{T}^{-1}\right], \mathrm{m} \mathrm{d}^{-1}$ $k$ :

$K_{h}$ :

$\mathrm{km}$ :

$K_{v}:$

L:

Laramide Basin Fill:

Layer:

Lbf:

$L_{E}$ :

Leonardian:

$\mathrm{m}:$

$\mathrm{m}^{3}$ :

Ma:

model:

ModelMuse:

Model sequence:

Modeling time: permeability $\left[\mathrm{L}^{2}\right]$ depends only on the medium (not fluid) properties; it includes horizontal, $k_{h}$, and vertical, $k_{v}$, components

Horizontal hydraulic conductivity

Kilometer

Vertical hydraulic conductivity

(1) Dimensional unit of length, as in $[\mathrm{L}],\left[\mathrm{L}^{-1}\right]$, etc.

Layer (2), second from top, of the model. Age: the combined Paleogene and Neogene Periods (formerly the Tertiary Period). Terrestrial gravel, sand, and clay (also called Tertiary Sediments)

Vertically discrete element of each MODFLOW model. Each MODFLOW model is divided into 10 layers spanning the vertical direction and represents one or more geohydrologic unit(s)

Laramide Basin Fill

Land surface elevation in the east.

Upper part of the Permian, combined with the lower part of the Jurassic (Morrison formation) in layer (5)

Meters

Cubic meters

Mega annum, or millions of years ago

Same as "MODFLOW model"

Preprocessor program for MODFLOW: the user inputs values of MODFLOW model parameters, such as $K$, and ModelMuse creates files in the format required for MODFLOW input files

The same as "sequence of [MODFLOW] models"

Time counted from the beginning of modeling, which starts at $40 \mathrm{Ma}$. So, modeling time of 0 is $40 \mathrm{Ma}$; a modeling time of 13 million years is $27 \mathrm{Ma}$ because there are 13 million years from 40 to $27 \mathrm{Ma}$, and so on 
MODFLOW:

MODFLOW model:

m.y.:

Neogene Period:

no.:

Og:

Ogallala Formation:

OM:

Optimal values of underflow Values of underflow and $K$ and $K$ :

\section{$p:$ \\ Paleogene Period:}

Percent of total uplift:

Potential:

Potentiometric surface map: Map of the $\left(K_{h}\right.$ and $\left.K_{v}\right)$ that make the calculated present-day hydraulic head values as close as possible to the actual present-day hydraulic head values

Pressure, $\left[\mathrm{F} \mathrm{L}^{-2}\right]$

Early part of the former Tertiary Period, consisting of the Paleocene, Eocene, and Oligocene Epochs PTU. Uplift between MODFLOW model times, such as between the $27 \mathrm{Ma}$ and 18 Ma models, represented as a percent of total uplift

Driving force in physics where a physical quantity like heat or mass moves from high to low potential values. In groundwater flow, the potential is the hydraulic head three-dimensional potential surface, represented as contours lines of equal potential, or equal hydraulic head

\begin{tabular}{|c|c|}
\hline Present-day: & $\begin{array}{l}\text { Describes current } \\
\text { conditions, at } 0 \mathrm{Ma} \text {, as } \\
\text { opposed to in the geologic } \\
\text { past }\end{array}$ \\
\hline PTU: & Percent of total uplift \\
\hline Q: & Flow rate $\left[\mathrm{L}^{3} \mathrm{~T}^{-1}\right]$ \\
\hline$Q_{w}:$ & $\begin{array}{l}\text { Flow rate specified at the } \\
\text { west end of the model }\end{array}$ \\
\hline$q:$ & $\begin{array}{l}\text { Flux; flow rate }\left[\mathrm{L}^{3} \mathrm{~T}^{-1}\right] \text { per } \\
\text { unit area }\left[\mathrm{L}^{2}\right] \text {, so equal to } \\
{\left[\mathrm{L} \mathrm{T}^{-1}\right]}\end{array}$ \\
\hline$q_{w}:$ & $\begin{array}{l}\text { Flux specified at the west } \\
\text { end of the model }\end{array}$ \\
\hline$q_{h}:$ & $\begin{array}{l}\text { Flux in the horizontal, } h \text {, } \\
\text { direction }\end{array}$ \\
\hline resp.: & Respectively \\
\hline S: & $\begin{array}{l}\text { Storage coefficient } \\
\text { (storativity). The volume of } \\
\text { water, } \mathrm{L}^{3} \text {, released from a } \\
\text { unit area of the aquifer, } \mathrm{L}^{2} \text {, } \\
\text { per unit drop in head, L. So, } \\
\text { units of }\left(\mathrm{L}^{3} \mathrm{~L}^{-2}\right) \mathrm{L}^{-1}=1 \text {, that } \\
\text { is, dimensionless }\end{array}$ \\
\hline
\end{tabular}

Sequence of [MODFLOW] A sequence of 9 MODFLOW models:

models representing the structural, depositional, and erosional changes from $70 \mathrm{Ma}$ to the present, the same as "model sequence"

$S_{s}:$

STP:

$t$ :

$\mathrm{T}:$ Specific storage $=S$ per unit height of aquifer, L. So, units of $1 \mathrm{~L}^{-1}, \mathrm{~m}^{-1}$

Standard temperature and pressure Time in millions of years, can be $27 \mathrm{Ma}, 18 \mathrm{Ma}$, and so forth

(1) Dimensional unit of time, as in $[\mathrm{T}],\left[\mathrm{L} \mathrm{T}^{-1}\right]$, and so forth in days, $\mathrm{d}$, and (2) transmissivity

The present: Total Uplift

TU:

Underflow:

Underpressure:
USGS:

$v$ :
Current, at $0 \mathrm{Ma}$ (TU): Total uplift from $27 \mathrm{Ma}$ to the present Total uplift Groundwater flow entering an aquifer from another aquifer bordering it The amount that the hydraulic head at a location is lower than the water table. For this report, this is approximated by the amount that the hydraulic head is lower than land surface US Geological Survey the subscript $v$, as in $K_{v}$, indicates the vertical direction 
Vector \{\} :

Vertical datum:

Virg:

W:

West:

Wolfc:

$x$-direction:

$\mathbf{x}:$

$\mathbf{x}_{\mathrm{c} 1}$ :

$\mathbf{x}_{\mathrm{c} 2}$ :

$y$-direction:

yr:

$z$ :

$z$-direction:
List of values

Reference for elevation in the vertical direction, taken in this report to be mean sea level

Virgilian geohydrologic unit

West

The left side of all figures in the report is aligned with the geographic west

The Wolfcampian, Permian, geohydrologic unit

The horizontal direction from west to east

Distance to the east of the

Golden Fault (in m). Graphically shown in km $\mathbf{x}$ at cell 1

$\mathbf{x}$ at cell 2

The horizontal direction from south to north. For this 2-dimensional vertical model, there is no flow in the $y$-direction and the model width in the $y$-direction is $100 \mathrm{~m}$ Year Elevation head, or elevation ASL, in (A.1)

The vertical direction, from low elevation to high elevation.

\section{Disclosure}

Philip H. Nelson, Chris Fridrich, and Gary D. LeCain are Emeritus.

\section{Conflicts of Interest}

The authors declare that there are no conflicts of interest regarding the publication of this paper.

\section{Acknowledgments}

The authors are grateful to the US Geological Survey Carbon Sequestration Program, which funded this work for several years, and for its director, Peter Warwick who also reviewed the manuscript and provided valuable input. They thank Geoffrey Delin of the USGS for his thorough review and request to clearly present our model sensitivity analysis.

\section{References}

[1] J. T. Hack, "Landforms of the United States," U.S. Geological Survey, U.S. Department of the Interior, general interest [physical] publication (pamphlet), U.S. Government Printing Office, 1982.
[2] J. T. Hack, Landforms of the United States, U.S. Geological Survey, USGS Publications Warehouse, 1988, scanned version of (Hack, 1982).

[3] K. Belitz and J. D. Bredehoeft, "Hydrodynamics of Denver basin: explanation of subnormal fluid pressures," The American Association of Petroleum Geologists Bulletin, vol. 72, no. 11, pp. 1334-1359, 1988.

[4] V. Cotner and H. E. Crum, "Geology and occurrence of natural gas in Amarillo District, Texas," in Geology of Natural Gas: A Symposium, H. A. Ley, Ed., pp. 385-415, American Association of Petroleum Geologists, 1935.

[5] F. A. F. Berry, Hydrodynamics and chemistry of the Jurassic and Cretaceous Systems in the San Juan basin [Ph.D. thesis], northwestern New Mexico and southwestern Colorado. Stanford University, Stanford, 1959, $\mathrm{PhD}$ thesis.

[6] W. L. Russell, "Reservoir water resistivities and possible hydrodynamic flow in Denver Basin," American Association of Petroleum Geologists Bulletin, vol. 45, pp. 1925-1940, 1961.

[7] P. H. Nelson, N. J. Gianoutsos, and R. M. Drake, "Underpressure in Mesozoic and Paleozoic rock units in the Midcontinent of the United States," AAPG Bulletin, vol. 99, no. 10, pp. 1861-1892, 2015.

[8] R. P. Sorenson, "A dynamic model for the Permian Panhandle and Hugoton Fields, western Anadarko Basin," AAPG Bulletin, vol. 89, no. 7, pp. 921-938, 2005.

[9] P. A. Macfarlane, "The effect of river valleys and the Upper Cretaceous aquitard on regional flow in the Dakota aquifer in the central Great Plains of Kansas and southeastern Colorado," Kansas Geological Survey Bulletin, vol. 238, part 2, pp. 11-30, 1995.

[10] A. W. Harbaugh, The U.S. Geological Survey Modular GroundWater Model-the Ground-Water Flow Process, U.S. Geological Survey Techniques and Methods 6-A16, p. 253, 2005.

[11] G. P. Eaton, "Topography and origin of the southern Rocky Mountains and Alvarado Ridge," in Continental Extensional Tectonics, M. P. Coward, Ed., vol. 28, pp. 355-369, Geological Society of London Special Publication, 1987.

[12] G. P. Eaton, "Epeirogeny in the southern Rocky Mountains region: evidence and origin," Geosphere, vol. 4, no. 5, pp. 764784, 2008.

[13] D. E. Trimble, "Cenozoic Tectonic History of the Great Plains," in Cenozoic History of the southern Rocky Mountains, B. F. Curtis, Ed., vol. 144 of Geological Society of America Memoir, pp. 227-248, 1980.

[14] P. L. Heller, K. Dueker, and M. E. McMillan, "Post-Paleozoic alluvial gravel transport as evidence of continental tilting in the U.S. Cordillera," Bulletin of the Geological Ions Society of America, vol. 115, no. 9, pp. 1122-1132, 2003.

[15] R. B. Winston, "ModelMuse-A graphical user interface for MODFLOW-2005 and PHAST," U.S. Geological Survey Techniques and Methods 6-A29, 2009.

[16] D. C. Signor, J. O. Helgesen, D. G. Jorgensen, and R. B. Leonard, "Geohydrology and simulation of steady-state flow conditions in regional aquifer systems in Cretaceous and older rocks underlying Kansas, Nebraska, and parts of Arkansas, Colorado, Missouri, New Mexico, Oklahoma, South Dakota, Texas, and Wyoming," US Geological Survey Professional Paper, vol. 1414C, 1996.

[17] H. S. Carslaw and J. C. Jaeger, Conduction of Heat in Solids, Oxford at the Clarendon Press, 1959. 
[18] M. E. McMillan, C. L. Angevine, and P. L. Heller, "Postdepositional tilt of the Miocene-Pliocene Ogallala Group on the western Great Plains: evidence of late Cenozoic uplift of the Rocky Mountains," Geology, vol. 30, no. 1, pp. 63-66, 2002.

[19] R. A. Duller, A. C. Whittaker, J. B. Swinehart et al., "Abrupt landscape change post-6 Ma on the central Great Plains, USA," Geology, vol. 40, no. 10, pp. 871-874, 2012.

[20] D. Sahagian, "Epeirogeny and eustatic sea level changes as inferred from Cretaceous shoreline deposits: applications to the central and western United States," Journal of Geophysical Research, vol. 92, no. B6, pp. 4895-4904, 1987.

[21] S. M. Cather, C. E. Chapin, and S. A. Kelley, "Diachronous episodes of Cenozoic erosion in southwestern North America and their relationship to surface uplift, paleoclimate, paleodrainage, and paleoaltimetry," Geosphere, vol. 8, no. 6, pp.11771206, 2012.

[22] R. L. Christiansen and P. W. Lipman, "Cenozoic volcanism and plate-tectonic evolution of the western United States," II. Late Cenozoic. Philosophical Transactions of the Royal Society A, vol. 271, pp. 249-284, 1972.

[23] H. D. MacGinitie, Fossil Plants of the Florissant Beds, Colorado, vol. 599, Carnegie Institute of Washington Contributions to Paleontology, 1953.

[24] D. Sahagian, A. Proussevitch, and W. Carlson, "Timing of Colorado Plateau uplift: Initial constraints from vesicular basaltderived paleoelevations," Geology, vol. 30, no. 9, pp. 807-810, 2002.

[25] R. M. Flowers, B. P. Wernicke, and K. A. Farley, "Unroofing, incision, and uplift history of the southwestern Colorado Plateau from apatite (U-Th)/He thermochronometry," Bulletin of the Geological Society of America, vol. 120, no. 5-6, pp. 571587, 2008.

[26] K. E. Karlstrom, D. Coblentz, K. Dueker et al., "Mantledriven dynamic uplift of the Rocky Mountains and Colorado Plateau and its surface response: toward a unified hypothesis," Lithosphere, vol. 4, no. 1, pp. 3-22, 2012.

[27] J. C. Frye, "Valley erosion since pliocene 'algal limestone' deposition in Central Kansas," Kansas Geological Survey Bulletin, vol. 60, part 3, no. 5, pp. 647-655, 2008, http://www.kgs.ku.edu/ Publications/Bulletins/60_3/index.html.

[28] M. E. McMillan, P. L. Heller, and S. L. Wing, "History and causes of post-Laramide relief in the Rocky Mountain orogenic plateau," Bulletin of the Geological Society of America, vol. 118, no. 3-4, pp. 393-405, 2013.

[29] Keefer W. R., "Structural geology of the Wind River Basin, Wyoming," US Geological Survey Professional Paper, 1970.

[30] G. A. Izett, "Late Cenozoic sedimentation and deformation in northern Colorado and adjoining areas," Geological Society of America Memoirs, vol. 144, pp. 179-209, 1975.

[31] R. K. Senger and G. E. Fogg, "Regional underpressuring in deep brine aquifers, Palo Duro Basin, Texas: 1. effects of hydrostratigraphy and topography," Water Resources Research, vol. 23, no. 8, pp. 1481-1493, 1987. 

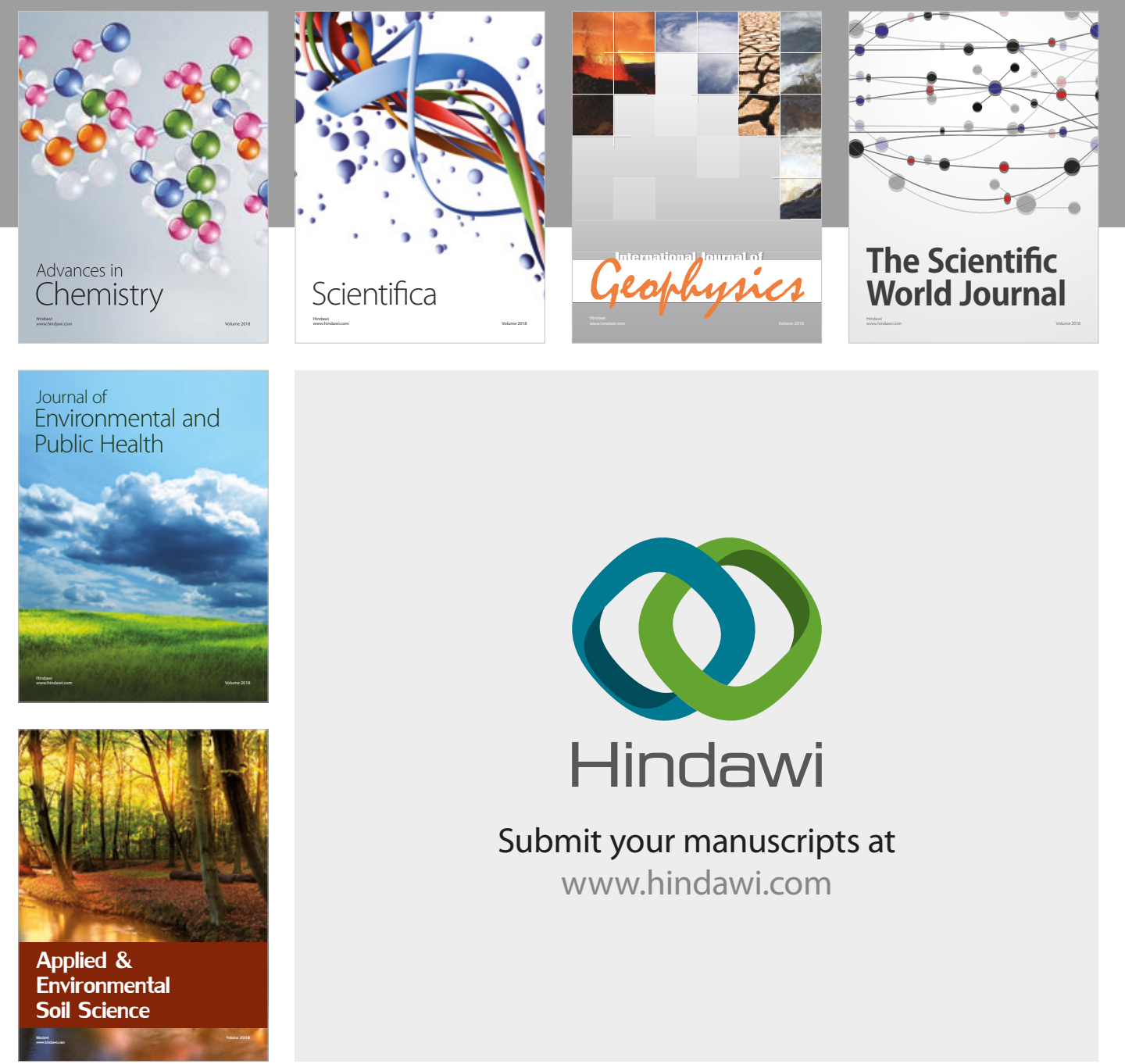

The Scientific

\section{World Journal}
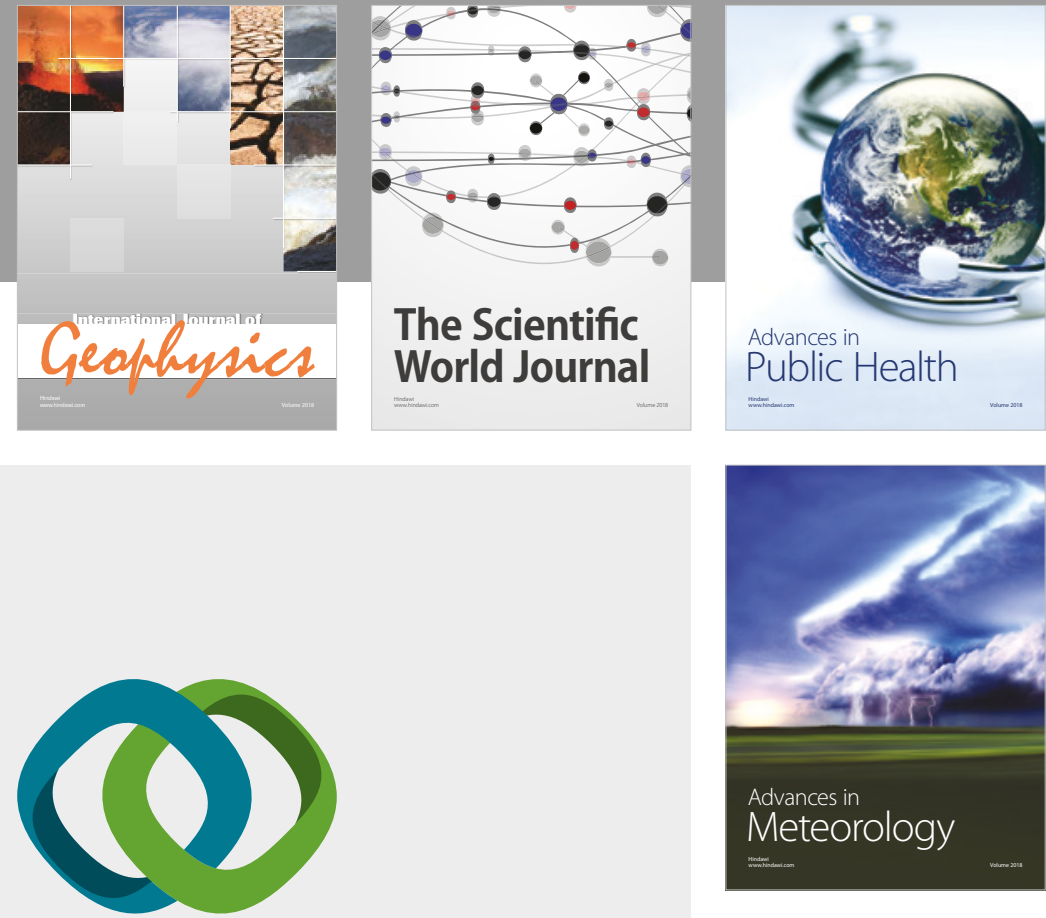

Advan

Public Health

\section{Hindawi}

Submit your manuscripts at

www.hindawi.com
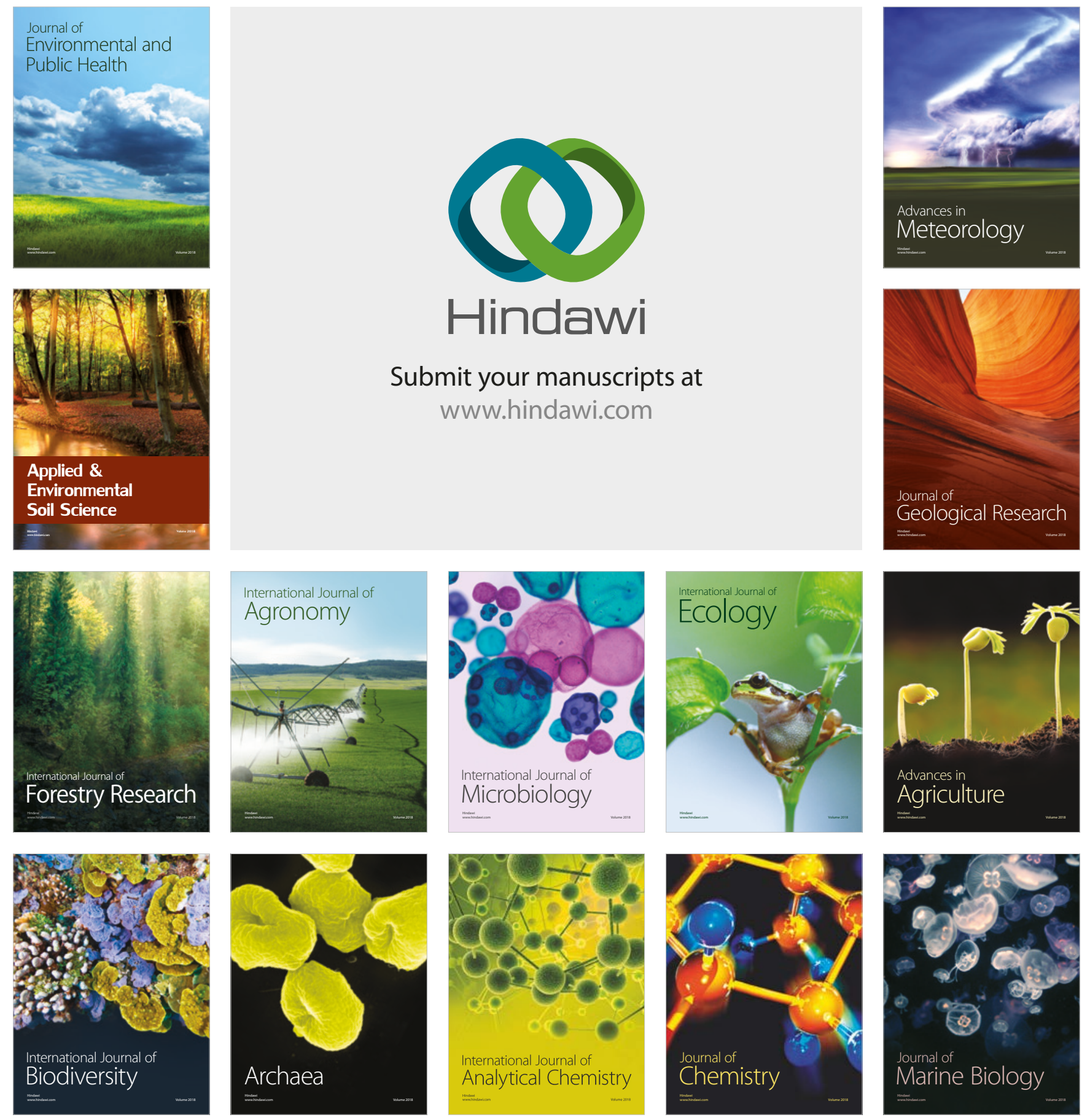